\title{
Is Disinflation Good for the Stock Market?
}

\author{
Peter Blair Henry
}

Center on Democracy, Development, and The Rule of Law

Freeman Spogli Institute for International Studies

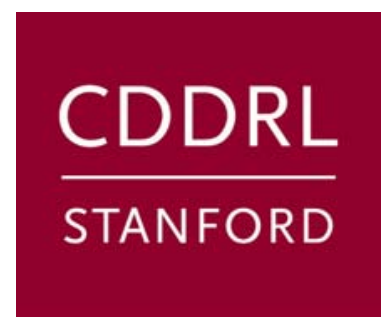

This working paper was produced as part of CDDRL's ongoing programming on economic and political development in transitional states. Additional working papers appear on CDDRL's website:

http://cddrl.stanford.edu. 
Center on Democracy, Development, and The Rule of Law

Freeman Spogli Institute for International Studies

Stanford University

Encina Hall

Stanford, CA 94305

Phone: 650-724-7197

Fax: 650-724-2996

http://cddrl.stanford.edu/

\section{About the Center on Democracy, Development and the Rule of Law (CDDRL)}

CDDRL was founded by a generous grant from the Bill and Flora Hewlett Foundation in October in 2002 as part of the Stanford Institute for International Studies at Stanford University. The Center supports analytic studies, policy relevant research, training and outreach activities to assist developing countries in the design and implementation of policies to foster growth, democracy, and the rule of law.

\section{About the Author}

Peter Blair Henry is Associate Professor of Economics in the Graduate School of Business at Stanford University (tenured). His work focuses on international finance, economic growth and development. The National Science Foundation's Early CAREER Development Program supports his research on the effects of economic policy reform in emerging markets. He has published extensively in books and economic journals, including the Journal of Financial Economics, Journal of Finance, American Economic Review. He previously served as a consultant to the Bank of Jamaica (1995) and a consultant to the Eastern Caribbean Central Bank (1994). He was a Rhodes Scholar from 1991 to 1993. He is a Non-resident Senior Fellow at the Brookings Institution; Associate Director, Center for Global Business and the Economy at Stanford GSB; faculty research fellow in the International Finance and Macroeconomics Program of the National Bureau of Economic Research; and CDDRL senior fellow. Peter B. Henry received a BA in economics from the University of North Carolina at Chapel Hill in1991; a BA from Oxford University in 1993; and a PhD in economics from the Massachusetts Institute of Technology in 1997. In 1999, he received the National Economic Association's award for best doctoral thesis in economics. 


\title{
Is Disinflation Good for the Stock Market?
}

\author{
Peter Blair Henry ${ }^{*}$
}

\footnotetext{
*Henry is Associate Professor of Economics, Stanford University, Graduate School of Business, and Faculty Research Fellow, National Bureau of Economic Research. I am grateful to Christian Henry, Langston Henry, and Lisa Nelson for their support and encouragement. I thank Steve Buser, Diana Kirk, Paul Romer, and anonymous referees for detailed comments on earlier drafts. I also thank Olivier Blanchard; Geert Bekaert; John Campbell; Anusha Chari; Richard Clarida; Pat Conway; Rudi Dornbusch; Bob Flanagan; Bob Hall; Andy Karolyi; Greg Mankiw; Maureen O’Hara; Jim Poterba; Hélène Rey; Roberto Rigobon; Tom Sargent; Andrei Shleifer; Ken Singleton; Jeremy Stein; René Stulz; Ewart Thomas; Carlos Végh; Jim Van Horne; Ingrid Werner; and seminar participants at the AEA Summer Program at UC-Denver, AFA, University of Chicago, Hoover Institution, IMF, London Business School, MIT, the NBER, Ohio State, Stanford, and the World Bank for helpful comments. Serkan Arslanap, Joanna Campbell, Begna Gebreyes, Chad Milner, Nora Richardson, and Laura Veldkamp provided stellar research assistance. I thank The Dice Center for Financial Economics at Ohio State University for providing a stimulating research environment. I also thank the Hoover Institution, where much of this paper was written during my year as a National Fellow. Financial support from the Stanford Institute for Economic Policy Research (SIEPR) and an NSF CAREER award is gratefully acknowledged. Finally, I would like to thank Robert Solow for encouraging me to pursue the idea. Any errors are my own.
} 


\begin{abstract}
The stock market appreciates by an average of 24 percent in real dollar terms when countries attempt to stabilize annual inflation rates that are greater than 40 percent. In contrast, the average market response is 0 when the pre-stabilization rate of inflation is less than 40 percent. These results suggest that the potential long-run benefits of stabilization may dominate short-run costs at high levels of inflation, but at low to moderate levels of inflation, benefits may be offset by costs in a present value sense. Stock market responses also help predict the change in inflation and output in the year following all 81 stabilization efforts.
\end{abstract}


Larry Summers argues that there is an absence of sound research on major questions that fall between standard finance and economics approaches (Summers, 1985). Almost twenty years later, his contention still rings true with respect to issues of disinflation and the stock market. A large literature in finance studies the effect of inflation on stock returns (Fama and Schwert (1977), Fama (1981), Modigliani and Cohn (1979), Schwert (1981)). But none of these papers analyzes stock market responses to disinflation programs. When a government announces the start of a disinflation program, it signals its intention to significantly cut the rate of inflation. There is no better setting for determining whether inflation affects stock returns. If inflation matters, then stock prices should immediately reflect the news that future inflation will be lower than its current level.

On the other hand, a large literature in macroeconomics studies the social cost of disinflation (Friedman (1968), Lucas (1973), Okun (1978), Phelps (1968), Tobin (1972)). Yet none of these papers or subsequent ones in this tradition make use of stock prices. Instead, macroeconomists assess the social cost of disinflation by constructing the sacrifice ratio (Ball (1994), Fischer (1986), Gordon (1982), Okun (1978)). The sacrifice ratio measures the short-run cost of reducing inflation as the sum of undiscounted output losses over some horizon. This approach assumes that there are long-run benefits to reducing inflation without making them explicit in a cost-benefit calculation. Therefore, sacrifice-ratio-based analyses do not tell us whether the benefits of disinflation outweigh the costs.

In contrast, the net present value analysis of disinflation introduced here focuses attention on the central issue: Do the benefits of reducing inflation outweigh the costs? 
Changes in stock prices reflect both revised expectations about future corporate profits and the discount rate at which those profits are capitalized. Contractionary measures taken to reduce inflation may raise discount rates and reduce profits in the short run. But the reduction in inflation may increase future profits and reduce discount rates. The stock market response to an unanticipated announcement of a disinflation program removes the temporal dimension of the analysis by collapsing the entire expected future stream of disinflation costs and benefits into a single summary statistic: the expected net benefit (current and future) of the program.

The average unanticipated stock market response associated with the 81 disinflation episodes studied in this paper is estimated empirically using standard event study technology. The results show that stock markets appreciate by an average of 24 percent in real dollar terms when countries attempt to stabilize annual inflation that is high (above 40 percent). In contrast, the average market response is zero if the prestabilization inflation rate is moderate (below 40 percent). Stock market responses also help predict the change in inflation and output in the year following all stabilization efforts.

The results are not sensitive to the particular definitions of high and moderate inflation, which are taken from Easterly (1996) and Dornbusch and Fischer (1993). The same conclusion is also reached for stock market responses conditional on alternative classifications of high and moderate inflation.

Reporting the results in real dollar terms requires caution, however. In countries with high inflation, the rate of depreciation of the official nominal exchange rate may not keep pace with inflation. Under such a scenario, the real dollar value of the stock market 
may become artificially inflated. To account for this possibility, the central estimations are also performed using real local-currency stock returns. They yield the same result. The stock market responds in a positive and statistically significant manner when a country attempts to stabilize high inflation, but there is no significant market response if the pre-stabilization inflation rate is moderate.

It is important to know whether this result is driven by variation in the types of stabilization policies used in high versus moderate inflation. The data suggest that this is not the case. Sixty-nine of the 81 stabilization programs studied in this paper are identified by IMF agreements. The International Monetary Fund (IMF) has been criticized in recent years for the uniformity of its policy prescriptions in all country agreements, irrespective of differences in initial macroeconomic conditions and in country-specific idiosyncrasies (Corden (1998)). The homogeneity of the Fund's stabilization prescriptions across countries suggests that there are not major differences between the packages of stabilization policies pursued in the high and moderate inflation subsamples.

If countries attempt to reduce inflation without help from the IMF, however, then they may pursue stabilization policies that differ significantly from those prescribed by the Fund. For example, 12 of the 81 stabilization episodes studied in this paper did not involve an official agreement with the IMF. All 12 of these programs were directed at stabilizing high inflation. In eight of these 12 episodes, countries attempted to stabilize inflation by fixing the nominal exchange rate. In contrast, none of the IMF episodes involved exchange-rate-based stabilizations (ERBS). Furthermore, there is an extensive literature that demonstrates that the short-run real effects of ERBS differ substantially 
from those observed in more traditional stabilization programs, such as those pursued by the Fund (Végh (1992), Calvo and Végh (1998), Fischer, Sahay, and Végh (2002)). Therefore, it is important to investigate whether the differential stock market responses are driven by differences between IMF and non-IMF stabilization policies. Various robustness checks in Section II suggest that this is not the case.

After grappling with concerns about robustness, Section III turns to the issue of how to interpret the central result. Stabilizing high inflation increases the present value of shareholders' claims, whereas stabilizing moderate inflation has no effect. The principle question is: Do the results imply that stabilizing high inflation increases the present value of aggregate output, while stabilizing moderate inflation does not? This question must be addressed with caution. Stabilizing inflation could increase capital's share in Gross Domestic Product (GDP). In turn, increasing capital's share in GDP could generate higher future profits (and therefore stock prices), even if stabilization has no effect on GDP levels or growth rates. Therefore, we cannot conclude that stabilizing high inflation increases the present value of aggregate output. More generally, conclusions about the effect of disinflation on the present value of aggregate output cannot be inferred directly from the stock market responses.

Accordingly, Section III of the paper pursues a narrower question. Do stock market responses to disinflation announcements rationally forecast future outcomes for the economy, apart from the publicly traded corporate sector? Two approaches are employed. To the extent that the stock market responses reflect the expected change in the present value of profits from stabilizing inflation, they should have some predictive power for the ex-post change in inflation. Hence, the first approach asks whether the 
stock market responses help predict future changes in inflation. The second approach explores whether the stock market responses help predict future changes in GDP growth. While these two approaches do not provide definitive evidence, the stock market responses do help predict the change in inflation and output in the year following efforts to stabilize both high and moderate inflation. This additional result indicates that the stock market evidence for the 81 inflation stabilization programs studied here is not spurious.

\section{Data and Descriptive Findings}

The data construction involves three steps: country selection and assembly of the raw data; identification of disinflation announcements; and classification of the level of inflation at the time the announcements were made.

The sample includes all countries that (1) have publicly available stock market data and (2) have undertaken at least one disinflation since their stock market data became readily available. The 21 countries that satisfy both criteria are Argentina, Brazil, Chile, Egypt, India, Indonesia, Israel, Jamaica, Jordan, Kenya, Korea, Mexico, Nigeria, Pakistan, Peru, the Philippines, South Africa, Thailand, Turkey, Venezuela, and Zimbabwe. The principal source of stock market data is the International Finance Corporation's (IFC) Emerging Markets Data Base (EMDB). Stock price indices for individual countries are the dividend-inclusive, U.S. dollar-denominated IFC Global Index. For most countries, EMDB's coverage begins in December 1975, but for others coverage only begins in December 1984. For those countries for which the IFC does not provide stock market data, the analysis uses the share price index given in the IMF's 
International Financial Statistics (IFS). Each country's U.S. dollar-denominated stock price index is deflated by the U.S. consumer price index (CPI), which comes from the IFS. All of the data are monthly. The consumer price index for each country is also obtained from the IFS. Returns and inflation are calculated as the first difference of the natural logarithm of the real stock price and CPI, respectively.

The announcement month and year of the 81 disinflation programs are identified using two sources. The first source of event dates is Calvo and Végh (1998). They identify the best-known programs that received a great deal of attention in the literature on inflation stabilization. The second source is the Annual Reports of the International Monetary Fund (IMF). These reports are used to construct a time series of months in which each of the 21 countries effectively announced their intention to stabilize by signing an official agreement with the IMF.

IMF programs typically call for current account stabilization in addition to inflation stabilization. The dual stabilization objectives of these programs do not introduce important biases into the dating procedure. The macroeconomic targets in IMF programs are generated by the IMF's Financial Programming Model, which is based on the monetary approach to the balance of payments. ${ }^{1}$ Under the monetary approach, balance of payments problems originate from an excess supply of money, with monetization of the government deficit typically seen as the proximate cause of the excess supply. The IMF requires that countries reduce both the fiscal deficit and the growth rate of the money supply in order to stabilize their current account. Thus, the prescription for stabilizing the current account is tantamount to a traditional disinflation program. 
Including the recent IMF agreements in Mexico in 1995, Asia in 1997, Russia in 1998, and Brazil in 1999 would strengthen the central findings of this paper, because these countries were experiencing moderate inflation and stock prices collapsed during the months leading up to their agreements with the IMF. Nevertheless, these episodes are excluded from the sample for two reasons. First, Dornbusch (1998a) argues that the synopsis of stabilization outlined in the preceding paragraph does not provide an accurate description of these recent episodes. He argues that the recent episodes were not inflation crises per se, but financial crises; the proximate cause was country balance sheets whose assets and liabilities were misaligned with respect to both maturity structure and currency denomination. Second, as part of these recent agreements, the IMF has imposed major structural and institutional reforms in addition to insisting on its traditional short-run stabilization objectives (Feldstein (1998)).

High inflation episodes are defined as in Easterly (1996) and Bruno and Easterly (1998): 12-month inflation in excess of 40 percent during each of the 24 months leading up to and including the month in which the stabilization was announced. Moderate inflation episodes are defined analogously: 12-month inflation between 10 and 40 percent during each of the 24 months leading up to and including the month in which the stabilization was announced. This definition of moderate inflation corresponds closely to that of Dornbusch and Fischer (1993).

Table A1 in the Appendix provides extensive details about all of the inflation stabilization programs identified using both data sources. The following is a partial summary of those data. Fourteen of the 81 disinflation announcements correspond to the beginning of Calvo and Végh (1998) episodes. Two of the fourteen Calvo and Végh 
episodes coincided with IMF agreements Mexico in 1977 and Argentina in 1991. Thirteen of the 25 attempts at stabilizing high inflation have official IMF sponsorship, and seven succeeded in reducing high inflation to moderate inflation. Seventeen of the

25 episodes occurred in Argentina and Brazil. All 56 of the attempts at stabilizing moderate inflation have official IMF sponsorship, and five succeeded in reducing moderate inflation to low inflation.

\section{A. Descriptive Findings}

There are two key questions about the relationship between the stock market response to the announcement of a stabilization program and the pre-stabilization level of inflation. First, does the magnitude of the stock market response increase or decrease as a function of the level of initial inflation? Second, what is the sign of the stock market response and does the sign depend on the level of inflation?

\section{A.1. Is the Market Response an Increasing Function of Ex-Ante Inflation?}

Figure 1 provides a rough empirical answer to the first question: The net benefits of stabilization appear to be an increasing function of the level of ex-ante inflation. Month "0" is defined as the month in which a given stabilization program is announced. The IFC records the value of a country's stock market index at the end of the month. The data on stabilization events do not provide the day of the month on which programs are announced. These facts imply that the announcement of a given stabilization program may occur after the day of the month on which the IFC recorded prices. In such cases, the change in the stock market index in month [0] may not reflect the news of the 
stabilization event. Accordingly, Figure 1 plots the unadjusted cumulative change in the real dollar value of the stock market index in months $[0,+1]$ against the average 12month inflation rate over the two years prior to the announcement. Figure 1 suggests that the two-month stock price change is an increasing function of the ex-ante inflation rate. The higher the ex-ante inflation rate, the greater the stock price response when a stabilization program is announced.

The positive linear relationship apparent in Figure 1 is given by the following regression equation (robust $t$-statistics in parentheses, $\quad=0.10, \mathrm{~N}=81$ ):

The unconditional relationship is statistically significant, but the relationship is also noisy. There are a number of high inflation episodes for which the actual stock price change is close to zero. Explanations for these outliers are considered in Section III.A.

\section{A.2. Is the Sign of the Response Uniform Across All Ranges of Ex-Ante Inflation?}

Figure 1 shows that, on average, the expected net benefits of stabilizing appear to be roughly zero near the origin, but are often positive at high levels of inflation. Table I investigates this feature of the data for three different groupings of the 81 stabilization episodes based on levels of average inflation prior to announcement. The first grouping corresponds to the Bruno and Easterly (1998) classification of high versus moderate inflation; the second simply divides the total sample into two groups of equal size: high inflation (40 cases) and moderate inflation (41 cases). The third comparison splits the sample into three groups of equal size: high inflation (27 cases), moderate inflation (27 cases), and low inflation (27 cases). The alternative classification schemes are useful for 
checking whether the results are sensitive to the Bruno and Easterly inflation classification. In particular, the two-way numerical split creates a superset of the Bruno and Easterly high inflation episodes that is not dominated by Argentina and Brazil. Seventeen of the 25 Bruno and Easterly high inflation episodes are in Argentina and Brazil.

The first three rows of Table I report summary statistics for the number of country episodes, the median inflation rate and the median stock price response for the high and moderate categories under each inflation classification scheme. The fourth row identifies the number of country episodes for which the stock-price change over the two-monthannouncement window is less than the country-specific median two-month stock price change.

The last row of Table I reports the two-sided p-value of observing, at most, the corresponding number of two-month stock-price responses below their country-specific median two-month percentage stock-price change. The sign tests are significant at the one percent level for the high-inflation episodes under all three inflation classification schemes. The sign tests are never significant for the moderate-inflation episodes. These sign tests should be treated with caution, because they are based on raw returns. However, the consistency of the findings suggests that more careful measurements of the stock market response to stabilizing high versus moderate inflation may not be overly sensitive to any particular classification scheme. For brevity and comparability to previous work, the next section of the paper estimates the stock market response to stabilization conditional on inflation being high or moderate in the sense of Easterly (1996) and Bruno and Easterly (1998). 


\section{Methodology and Results}

Under the assumption that markets are efficient, a country's stock market index will adjust to information about changes in expected future profits or discount rates. Measuring the response of share prices to inflation stabilization events enables us to infer whether the expected net benefits of stabilizing inflation are positive or negative.

Following Stulz, Kho, and Lee (2000), the international capital asset pricing model is used to measure the expected return on each country's stock market index. The abnormal return associated with a stabilization event is the residual from this model. This implies a stochastic return generating process for country $i$ of the following form that is possibly affected by inflation stabilization events:

where is the real return in dollars on country $i$ 's stock market index in month $t, \quad$ is the real return in dollars on the Morgan Stanley Capital Market Index (MSCI) world stock market index in month $t, \quad$ is a dummy variable that is equal to one in highinflation-stabilization months $[0,+1]$ in country $i$, and is a dummy variable that is equal to one in moderate-inflation-stabilization months $[0,+1]$ in country i. The constant intercept term, , implicitly assumes perfect capital market integration. ${ }^{2}$ Alternative specifications that allow for country-specific intercepts are also examined and yield similar results.

The usual assumption that is a serially uncorrelated, random error term requires further discussion. Equation (2) is estimated using Feasible Generalized Least Squares (FGLS). An assumption of no serial correlation in stock returns could be 
justified on the grounds of rational expectations, but the estimation procedure will allow for the possibility of serial correlation. The estimation procedure also allows for heteroscedasticity across countries. However, with an unbalanced panel, it is not possible to relax the assumption of no contemporaneous correlation of the error term across countries. Therefore, a number of indirect precautions are taken.

First, short estimation windows are used in all of the central results; the assumption that country abnormal returns are not contemporaneously correlated is reasonable if event windows do not overlap in calendar time and overlaps occur less frequently with short windows. The HIGH and MODERATE stabilization dummies are on for two-month windows, [0, +1]. Estimates using one-month windows, [0], are also provided. Second, I investigated the extent to which contemporaneous correlation is likely to be a problem with short windows. With two-month estimation windows, 29 of the 162 event periods overlap. With one-month estimation windows, 11 of the 81 event periods overlap. These numbers suggest that a small fraction of the abnormal returns from (2) will potentially be affected by contemporaneous correlation. Third, two of the alternative regression specifications to equation (2) will estimate abnormal returns relative to the IFC's emerging stock market index. Since all of the sample countries are emerging markets, the inclusion of a composite emerging market index as a right-handside variable will partially control for contemporaneously correlated disturbance terms. Including the emerging market index does not change the results.

Equation (2) constrains the coefficient on HIGH to be the same across all months. Thus, the parameter measures the average monthly stock market response to all attempted stabilizations of high inflation. Similarly, measures the average monthly 
response to all attempted stabilizations of moderate inflation. Since the dummy variable for the event window is two-months long, the total stock market response to each type of stabilization attempt is given by two times the parameter estimate. A different estimation technique would be to use a seemingly unrelated regression (SUR). This approach would have the advantage of providing a unique coefficient estimate for each country for each event. However, there are also several disadvantages to this approach. First, the low power of hypothesis tests in unconstrained systems severely weakens the ability of the event study methodology to detect the impact of the event. Second, SUR requires a balanced panel. Due to the limited time series availability of stock market data, creating a balanced panel would result in discarding almost half of the 81 stabilization events. Given data limitations, the pooled cross-section time series framework seems appropriate.

\section{A. Responses to Disinflation Announcements: High Vs. Moderate Inflation}

In order to isolate the effects of disinflation, Panel A of Table II presents estimates of HIGH and MODERATE. The first row presents estimates from the benchmark specification given by equation (2). Heteroscedastic-consistent standard errors are reported in parentheses. The estimated coefficient on HIGH is 0.121 and is significant at the one-percent level. This means that the stock market increases by an average of 12.1 percent per month in real dollar terms when governments announce their intention to stabilize high inflation. Therefore, the total stock market increase associated with the HIGH announcement window is 24.2 percent in real dollar terms. The estimated coefficient on MODERATE is 0.001 and is not statistically significant. Therefore, the stock market response to disinflation announcements is not significantly different from 0 , 
when inflation is moderate. The column labeled "P-Value of HIGH > MODERATE" shows that the p-value for a test that the coefficient on HIGH equals the coefficient on MODERATE is 0.01 . Therefore, the coefficient on HIGH is significantly larger than the coefficient on MODERATE.

Table II also presents estimates of HIGH and MODERATE using alternative specifications. Row 2 presents estimates that use real U.S. stock returns, , in place of $R_{t}^{W}$ in equation (2). Row 3 presents estimates that use the real dollar return on the IFC Emerging Market index, , in place of $R_{t}^{W}$. Row 4 presents estimates that use all three sets of returns simultaneously. As an alternative to the market model in equation (2), Row 5 presents estimates based on simple mean-adjusted abnormal returns:

As a final specification, Row 6 presents estimates using a statistical model in which mean-returns may differ across countries by allowing for country-specific intercept terms:

Letting the intercept terms vary across countries allows for the possibility that average expected returns may differ across countries due to imperfect capital integration. ${ }^{3}$

The central result is the same under all six specifications. The stock market responds positively and significantly to the announcement of programs directed at stabilizing high inflation, with the average effect ranging from 11.3 to 12.2 percent per month. Thus, the total effect is between 22.6 and 24.4 percent. The response to announcements directed at stabilizing moderate inflation is small and never significant. The estimate of HIGH is always significantly larger than the estimate of MODERATE. 
Panel B of Table II also presents estimates based on month [0] only. These estimates closely match the month $[0,+1]$ estimates. In some cases, the month [0] estimate is smaller than the month $[0,+1]$ estimate, which suggests that not all of price change is captured in month [0].

As a final robustness check, the analysis explores whether the results are sensitive to whether real returns are measured in dollars or local currency units. The potential problem is that in high-inflation countries, the rate of depreciation of the nominal exchange rate may not keep pace with inflation. If inflation exceeds the rate of nominal depreciation, then the currency is appreciating in real terms, which means that the real dollar value of the stock market may become artificially inflated. In order to see whether the results in Table II are driven by real appreciation of the local currency vis-à-vis the dollar, all of the regressions were re-estimated using real local currency returns instead of real dollar returns as the left-hand-side variable. The results were virtually identical to the estimates that use dollar-denominated returns.

\section{B. Are the Differences Driven by Market Anticipation?}

When inflation is moderate, the stock price adjustment may occur in the months leading up to the disinflation announcement. Since the estimates in Table II measure the price response in the month of the disinflation announcement only, they may overstate the gap between the point estimates of HIGH and MODERATE. To explore this possibility, I use equation (2) to estimate abnormal returns and cumulative abnormal returns for the 12 months prior to the announcement of disinflation programs directed at high and moderate inflation.

Two important caveats are in order. First, an event window of this length may 
contain major events unrelated to disinflation. The estimates do not control for this possibility. Second, with long estimation windows, the problem of overlapping event windows is likely to be more severe and the standard errors are, therefore, more subject to problems stemming from cross-country correlation in the error term. Keeping these limitations in mind, the numbers may be useful in providing a crude sense of whether the market anticipates disinflation announcements.

Panel A of Table III presents the results. There is no substantial run-up in prices preceding high-inflation announcements. The cumulative abnormal return from month 12 to -1 is close to 0 . In the case of moderate inflation, the market experiences a cumulative drop of about 16 percent. Panel B presents estimates using equation (4). The results are the same. The fall in prices is consistent with the view that stabilization of moderate inflation is a negative net present value event for shareholders and the market anticipates these events. This fact reinforces the differences between high and moderate inflation evident in Table II.

\section{Are the Differences Driven by Differences in Disinflation Policies?}

The evidence in Sections II.A. and II.B. suggests two key results. The stock market responds positively and significantly when a country announces its intention to reduce high inflation. There is no significant market response if the pre-stabilization inflation rate is moderate. It is important to know whether these results are driven by variation in the types of policies used to reduce high versus moderate inflation. The uniformity of IMF programs suggests that there are not major differences between the packages of stabilization policies pursued in IMF-sponsored attempts at stabilizing high and moderate inflation. However, 12 of the 81 stabilization episodes studied in this paper 
did not involve an official agreement with the IMF. All 12 of these programs were directed at stabilizing high inflation. In eight of these 12 episodes, the countries involved attempted to stabilize inflation by fixing the nominal exchange rate. In contrast, none of the IMF episodes involved exchange-rate-based stabilizations (ERBS). Therefore, it is important to investigate whether the differential stock market responses are driven by differences between IMF and non-IMF stabilization policies.

Three robustness checks suggest that this is not the case. First, the average stock market response to the announcement of an ERBS is statistically indistinguishable from the average response to the announcement of a non-ERBS. Second, the difference between the average stock market response to disinflation announcements during high and moderate inflation remains economically and statistically significant when the nonIMF-sponsored programs are excluded from the high inflation sample. Third, there is no significant difference between the average stock market reaction to the attempted stabilization of high inflation in the IMF and non-IMF subsamples. Subsections II.C.1 and II.C.2 provide the details about these robustness checks.

\section{C.1. Are the High Results Due to Exchange-Rate-Based Stabilizations?}

There is an extensive literature on inflation stabilization in developing countries, which demonstrates that countries experience output booms when they reduce inflation by fixing the nominal exchange rate (Calvo and Végh (1998), Fischer et al. (2002), Végh (1992)). All of the ERBS episodes in this paper were implemented during high-inflation regimes. Therefore, this subsection investigates whether the positive and significant stock market response to disinflation announcements during high inflation is unique to 
ERBS, or is a more general outcome associated with stabilizing high inflation.

In order to address this issue, the 25 attempts at stabilizing high inflation are split into two groups: those that were exchange-rate-based and those that were not. A total of eight of these 25 episodes are identified as exchange-rate-based stabilizations by Calvo and Végh (1998) and Fischer et al. (2002). After separating these two kinds of stabilizations, the following panel regression is estimated:

where is a dummy variable that equals 1 in months $[0,+1]$ of all nonexchange-rate-based attempts at stabilizing high inflation, and is a dummy variable that equals 1 in months $[0,+1]$ of all exchange-rate-based attempts at stabilizing high inflation.

Panel A of Table IV shows that the estimated coefficients on ERBS range from 10.5 to 15.2 percent per month, and all are significant at the one-percent level. The point estimates of the coefficient on NONERBS range from 10.2 to 12.1 percent per month and are also significant at the one-percent level. The column labeled "P-Value of $E R B S>N O N E R B S$ " shows that the p-value for an F-test that the coefficient on ERBS is significantly different from the coefficient on NONERBS is not significant for any specification in Table IV. Therefore, the point estimates of ERBS are statistically indistinguishable from those for NONERBS.

The evidence in Table IV, taken together with the evidence in Table II, suggests that the stock market responds more favorably to the announcement of stabilization programs directed at high inflation than to those directed at moderate inflation, regardless of whether the stabilization program is exchange-rate-based or not. Thus, the stock 
market evidence also supports the finding that output booms are not limited to exchangerate-based stabilizations of high inflation (Easterly (1996)). However, this point should not be overstated, because the results are based on relatively few observations (25 total, eight ERBS).

\section{C.2. Are the High Results Driven by Differences in IMF and Non-IMF Programs?}

Two additional sets of empirical tests suggest that the differential stock market responses are not driven by differences between IMF and non-IMF stabilization policies. For brevity, only the results are reported—no tables are presented. First, the stock market response to high and moderate inflation announcements were re-estimated, excluding the non-IMF-sponsored programs from the high inflation sample. Specifically, a new dummy variable called IMFHIGH was created. This variable takes on the value one, just in those cases where attempts to stabilize high inflation were announced through an official IMF agreement. The coefficient on IMFHIGH was positive, significant, and significantly different than the coefficient on MODERATE. Thus, the difference between the average stock market response to high and moderate inflation announcements remains economically and statistically significant when the non-IMFsponsored programs are excluded from the high inflation sample.

Second, estimations were performed to compare the mean response of the stock market to IMF and non-IMF sponsored attempts at stabilizing high inflation. The coefficients on IMFHIGH and NONIMFHIGH were both positive and significant. However, the hypothesis that IMFHIGH=NONIMFHIGH could not be rejected. Thus, the evidence suggests that there is no significant difference between the average stock 
market reaction high inflation announcements in the IMF and non-IMF subsamples. Overall, the evidence in this subsection and in II.C.1 suggest that the central empirical result is not driven by differences in the way countries attempt to stabilize high versus moderate inflation.

\section{Does the Stock Market Get It Right?}

This section of the paper asks whether the stock market rationally forecasts stabilization outcomes. The analysis employs three approaches. The first approach examines if controlling for previous failed stabilizations strengthens the positive relationship between the stock market response and the ex-ante inflation rate. The second approach asks whether the stock market responses to disinflation announcements help predict future changes in inflation. The third approach explores whether the market responses help predict future changes in GDP growth.

\section{A. Stock Market Responses and Ex-Ante Inflation Rates Revisited}

If the stock market is rational, then it may assign a lower probability of success to a disinflation program that is announced on the heels of a failed program. A lower probability of success will decrease the stock market response to news of stabilization. Therefore, a low probability of success may explain why the stock price change is close to zero for a number of high-inflation episodes in Figure 1. This discussion suggests that the relationship between the stock market response and ex-ante inflation after controlling for past failures should be stronger than the unconditional relationship documented in Section I.A.1. Two approaches speak to the issue.

First, I re-estimate equation (1). This time I interact the inflation rate with a 
variable called PREVFAIL. The variable PREVFAIL is equal to one if there was a failed stabilization in the previous 24 months (robust t-statistics in parentheses $R^{2}=0.22$, $\mathrm{N}=81)$ :

The conditional relationship between the stock market change and the average prestabilization inflation rate is stronger than the unconditional one. Relative to equation (1), the coefficient on INFL in equation (6) is higher, the robust t-statistic is larger, and the R-squared is bigger. The interactive term, INFL*PREVFAIL, also has the expected negative sign and is significant.

As a second pass at the data, Figure 2 plots the announcement-window stock price response versus the average 12-month inflation rate for only those episodes that were not preceded by a failed stabilization in the previous 24 months. There are 41 such episodes. Figure 2 and equation (7) below exhibit a tighter linear relationship between the stock price change and inflation than Figure 1 and equation (1), which do not control for past failures. The trend line in Figure 2 is given by the following equation (robust t-statistics in parentheses $R^{2}=0.48, \mathrm{~N}=41$ ):

\section{$(-0.9)(4.7)$.}

The outlier in the upper right hand corner of Figure 2 is Peru. In 1989 and 1990 the average inflation rate in Peru was 344 percent. Real GDP fell by 12.3 percent in 1989 and 5.5 percent in 1990. In August of 1990, Alberto Fujimori was inaugurated as the new prime minister and announced a sweeping stabilization program, which came to be known as "Fujishock." The stock market increased by 100 percent in real dollar terms 
between August and September. In 1991, inflation fell to 44 percent and real GDP grew by 6.7 percent. The positive linear relationship in Figure 2 remains significant if Peru is removed.

\section{B. Do the Stock Market Responses Predict Future Changes in Inflation?}

To the extent that stock market responses to the announcement of a disinflation program predict the expected net benefit that will accrue to shareholders as a result of reducing inflation, they should be negatively associated with future changes in inflation. Figure 3 examines whether the data support this prediction. The variable on the $y$-axis is the change in inflation: the average 12-month inflation rate in the year after the disinflation announcement minus the average 12-month inflation rate in the two years prior to the announcement. The variable on the $x$-axis is the cumulative stock market response over the months $[0,+1]$. The trend line in Figure 3 is given by the following equation (robust t-statistics in parentheses $R^{2}=0.05, \mathrm{~N}=81$ ):

$$
(-1.2)(-2.2)
$$

Stock price responses to disinflation announcements have some unconditional predictive power for what will happen to inflation in the year following stabilization efforts.

\section{Do the Stock Market Responses Predict Future GDP Growth?}

To the extent that stock market responses capitalize the expected net output benefits of reducing inflation, they should be positively associated with future 
innovations in GDP growth. Put another way, the unexpected change in the stock market should reflect the "news" about future GDP growth. If the sample mean of a country's growth rate is taken as a proxy of its expected future growth rate, then the deviation of GDP growth from its country-specific sample mean is a metric of the news in GDP growth.

Figure 4 compares the average deviation of real GDP growth in years $[0,+3]$ with the average deviation over the pre-stabilization period (years [-3, -1]), for all high inflation episodes. Region B, the area above the average pre-stabilization deviation, is substantially larger than Region A, the area below. Figure 5 compares the average deviation in stabilization years $[0,+3]$ with the average deviation over the prestabilization period, for all episodes of attempted stabilizations of moderate inflation. In this figure, Region B is not substantially larger than Region A. Overall, the comparisons appear at least roughly consistent with the discounted evidence provided by the stock market (Table II).

Figure 6 plots the GDP news measure versus the unexpected stock price change. The graph suggests that the stock market has predictive power. The corresponding regression confirms the statistical significance of the apparent relationship (robust tstatistics in parentheses $R^{2}=0.09, \mathrm{~N}=81$ ):

Equation (9) indicates that, on average, a 100 percent stock price response to the announcement of a disinflation predicts GDP growth in the following year that is 4.76 percentage points above its sample mean. This equation should not be given a causal interpretation. It does not say that the unexpected stock market change causes growth. 


\section{Discussion}

This paper uses the stock market to answer a fundamental question: Do the benefits of disinflation outweigh the costs? Contractionary measures taken to reduce inflation may raise discount rates and reduce profits in the short run. But reducing inflation may increase future profits and reduce discount rates. The stock market removes the time dimension of the analysis by collapsing the entire future stream of disinflation costs and benefits into a single summary statistic: the expected net present value of the program to shareholders.

In contrast to the net present value analysis introduced in this paper, sacrificeratio analyses of disinflation focus exclusively on the cost of reducing inflation. Traditional wisdom holds that efforts to reduce inflation will cause a fall in output in accordance with the Phillips Curve. Sacrifice-ratio analyses measure the short-run cost of reducing inflation as the undiscounted sum of this fall in output (Ball (1994), Fischer (1986), Gordon (1982), Okun (1978)). ${ }^{4}$ This approach assumes that there are long-run benefits to reducing inflation without making them explicit in a cost-benefit calculation. Therefore, sacrifice-ratio-based analyses do not tell us whether the benefits of disinflation outweigh the costs.

In contrast to the traditional view, advocates of rational expectations argue that disinflation need not be costly if policy makers credibly commit to reducing inflation. Sargent (1982) provides supporting evidence for the rational expectations view. He

presents case studies of four countries that abruptly halted post-World War I hyperinflations at virtually no cost to output. 
In fact, more recent work finds that countries may even experience output booms while stabilizing high inflation (Végh, 1992). Calvo and Végh (1998) document seven episodes of expansionary stabilization of high inflation. Fischer et al. (2002) document nine episodes. Easterly (1996) provides broader evidence against the traditional view of disinflation. He studies twenty-eight episodes of high inflation that were successfully stabilized and shows that output expanded on average. In contrast to the recent evidence that reducing high inflation is expansionary, Dornbusch and Fischer (1993) conclude that moderate inflation can be reduced to low inflation only at a substantial short-term cost to output. $^{5}$ This conclusion is based on their case study of four countries that successfully reduced moderate inflation to low inflation.

Taken together, this recent evidence seems to suggest that disinflation is expansionary when starting from high levels of inflation, but contractionary when inflation is moderate. However, these studies focus exclusively on episodes where inflation was successfully reduced. Calvo and Végh (1998) argue that selection bias clouds the interpretation of studies that focus exclusively on episodes where inflation was successfully reduced, instead of all attempts at stabilizing inflation.

To understand the theoretical content of Calvo and Végh’s argument, imagine that a country experiencing high inflation initiates a stabilization program. Now suppose that this country experiences a favorable output shock. The shock creates two measurement problems. First, it causes an output boom, which generates a specious positive correlation between stabilization and output growth. Second, the boom generates a windfall in tax revenue, which reduces the government's need for inflationary finance and, therefore, raises the probability of a successful stabilization. 
Figure 7 illustrates the empirical thrust of Calvo and Végh’s (1998) selection bias critique. The figure plots the average deviation of annual output growth from its sample mean for two subsets of the high inflation episodes studied in this paper: those that were successfully stabilized and those that were not. ${ }^{6}$ The line corresponding to the successful stabilizations suggests that reducing high inflation is expansionary, but it is also consistent with the view that stabilizations succeed because they coincide with favorable exogenous shocks.

The line corresponding to the unsuccessful stabilizations is also consistent with multiple interpretations. Countries may experience recessions because (1) stabilization policy is contractionary; (2) the government is not committed to reducing inflation; or (3) the economy is hit with adverse shocks. The general message of Figure 7 is that selective examination of ex-post realizations of GDP growth may not accurately measure the expected real effects of stabilization policy. In a world where people are rational and forward-looking, one ideally wants an ex-ante measure of the effect that the stabilization program is expected to have on current and future output.

This paper uses the stock market to provide just such an ex-ante measure. There are large expected net benefits to stabilizing high inflation the stock market increases by 24 percent in real dollar terms when governments announce disinflation programs in the midst of high inflation. But there are no apparent net benefits to reducing moderate inflation the point estimate is zero when disinflation programs are announced in the midst of moderate inflation, and there is even some evidence of a market decline in anticipation of these announcements. Taken together, these results buttress previous findings that the real consequences of stabilizing high and moderate inflation are very different. 


\section{Alternative Interpretations and Extensions}

There are important limitations inherent in the stock market approach to evaluating the real effects of disinflation. First, to the extent that disinflation announcements are anticipated, the measured unanticipated change in equity prices will understate the expected impact of disinflation. Second, stock price responses measure the change in real wealth that accrues to domestic shareholders, not utility gains per se. ${ }^{7} \mathrm{~A}$ shock that drives down stock market valuation may actually be welfare improving. For example, a rise in expected future productivity can decrease stock market value if the discount rate rises by more than the increase in expected future dividends (Lucas, 1978). Nevertheless, welfare improves.

Third, the stock market provides a cost-benefit analysis of current and expected future profits. This is not the same thing as a cost-benefit analysis of current and expected future output. Therefore, the results speak only to shareholder gains and losses. We cannot make broader inferences about social welfare. For example, stabilizing moderate inflation may generate private benefits for nonshareholders, even if it is of little consequence to shareholders. There may also be public benefits from reducing moderate inflation that are not captured in stock prices. Conversely, whereas shareholders benefit from stabilizing high inflation, the results do not necessarily imply that nonshareholders are also better off. If stabilizing high inflation increases capital's share in GDP, then stock prices may rise with no change (or even a fall) in expected future output.

Bearing these limitations in mind, the stock market data provide comprehensive evidence that efforts directed at reducing high inflation have different real implications 
than those directed at reducing moderate inflation. Future research should try and uncover the underlying mechanisms responsible for these differences.

It would be useful to know how much of the observed stock market responses are due to changes in discount rates versus profits. One approach might be to look at data on total market dividends and dividend yields. These data would allow one to decompose the stock market responses into changes in discount rates and cash flows using the dividend discount model as in Blanchard (1993) and Fama and French (2000). Unfortunately, these data are not available for the entire sample period in all countries. It would also be helpful to know which of the following drives the central result: a difference in net benefits, conditional on success, or differing probabilities of success. The current evidence is silent on this issue.

Other factors for which the analysis is unable to control may also drive the observed differences in stock market responses. For example, a detailed study of the tax systems of the 21 countries in the sample lies outside the scope of this paper, but the way in which inflation interacts with the taxation of financial assets may drive the observed differences between high and moderate inflation (Feldstein, 1980). Another possibility is that stabilizing high inflation may signal future macroeconomic reforms, whereas stabilizing moderate inflation does not (Bruno and Easterly (1996), Collins (1990)). If that is the case, then the stock market may respond more favorably to disinflation announcements during high inflation, even if there are no substantial differences in the expected real effects of stabilizing high versus moderate inflation per se.

Using short event windows reduces the chance that the results are contaminated by major events that are unrelated to stabilization, but even a short window does not 
entirely eliminate the concern. The evidence relating the stock market responses to future changes in inflation and GDP growth is also subject to a similar critique.

The potential for reverse causality also merits discussion. If strong economic performance drives policy-makers to initiate stabilization programs, then the estimated stock market response to attempts at stabilizing high inflation may be upward biased. The pre-stabilization-window evidence (Table III) and the data on GDP growth (Figures 4 and 5) do not suggest reverse causality, but the possibility cannot be dismissed.

Finally, all of the moderate inflation episodes are identified using IMF agreements. Section I of the paper provides evidence that suggests that IMF stabilization programs are tantamount to traditional disinflation programs. Suppose, however, that inflation reduction is not a major objective of IMF programs in economies experiencing moderate inflation. In this case, the results suggest that IMF programs are of no value to domestic shareholders when inflation stabilization is not a principal objective.

\section{Conclusion}

In spite of the limitations, we learn a lot by using financial data to study important macroeconomic issues. The traditional view says that disinflation is costly, because reducing inflation causes a fall in output in accordance with the Phillips Curve. The rational expectations view says that disinflation need not be costly if policy makers credibly commit to reducing inflation. The stock market approach underscores the myopia inherent in both views. The paramount issue is not whether disinflation is costly in the short run, but whether the benefits of disinflation outweigh the costs. 


\section{REFERENCES}

Agénor, Pierre-Richard, and Peter Montiel, 1996, Development Macroeconomics, (Princeton University Press, Princeton, NJ).

Ball, Laurence, 1994, What determines the sacrifice ratio?, in Monetary Policy, Mankiw, ed.: (University of Chicago Press, Chicago, IL).

Blanchard, Olivier Jean, 1993, Movements in the equity premium, Brookings Papers on Economic Activity, 2, 75-138.

Blanchard, Olivier Jean, 1999, Macroeconomics (Prentice, Hall Upper Saddle River, NJ,).

Bruno, Michael, and William Easterly, 1998, Inflation crises and long run growth, Journal of Monetary Economics, 41, (1), 3-26.

Bruno, Michael, and William Easterly, 1996, Inflation's children: Tales of crises that beget reforms, American Economic Review, 86, (2), 213-217.

Burton, David, and Stanley Fischer, 1998, Ending moderate inflations, in Cottarelli and Szpáry eds. Moderate Inflation: The Experience of Transition Economies. International Monetary Fund.

Calvo, Guillermo, and Carlos Végh, 1998, Inflation stabilization and balance of payments crises in developing countries, Handbook of Macroeconomics, Forthcoming.

Collins, Susan M, 1990, Lessons from Korean economic growth, American Economic Review, 80, (2),104-107.

Collins, Susan M., 1999, Capital flows to developing economies: Implications for saving and investment, Brookings Papers on Economic Activity, 143-169.

Corden, W. Max, 1998, The Asian crisis: Are the IMF prescriptions right, Working paper, Johns Hopkins University.

Dornbusch, Rudiger, 1998a, After Asia: New directions for the international financial system, Mimeo, MIT.

Dornbusch, Rudiger, 1998b, Containing high inflation, Mimeo, MIT.

Dornbusch, Rudiger, and Stanley Fischer, 1993, Moderate inflation, The World Bank Economic Review, 7, (1), 1-44.

Dornbusch, Rudiger, and Stanley Fischer, 1987, Macroeconomics (New York, New 
York, McGraw Hill).

Easterly, William, 1996, When is stabilization expansionary? Economic Policy, 22, 67107.

Fama, Eugene F, 1981, Stock returns, real activity, inflation, and money, American Economic Review, 71, 545-65.

Fama, Eugene F., and G. William Schwert, 1977, Asset returns and inflation, Journal of Financial Economics, 5, 115-146.

Fama, Eugene F., and Ken French, 2000, The equity premium, Working paper, University of Chicago.

Feldstein, Martin, 1980, Inflation and the stock market, The American Economic Review, 70, (5), 839-47.

Feldstein, Martin, 1998, Refocusing the IMF, Foreign Affairs.

Fischer, Stanley, 1986, Real balances, the exchange rate, and indexation: Real variables in disinflation, Quarterly Journal of Economics, 53, 27-49.

Fischer, Stanley, 1993, The role of macroeconomic factors in growth, Journal of Monetary Economics, 32, 482-512.

Fischer, Stanley, Ratna Sahay, and Carlos Vegh, 2002, Modern hyper and high inflations, Journal of Economic Literature.

Frankel, Jeffrey, 1994, Introduction, in Jeffrey A. Frankel, ed.: The Internationalization of Equity Markets, (University of Chicago Press: Chicago and London), 231-71.

Friedman, Milton, 1968, The role of monetary policy, American Economic Review, LVIII, (1), 1-17.

Gordon, Robert J, 1982, Why stopping inflation may be costly: Evidence from fourteen historical episodes, in R.E. Hall, ed.: Inflation: Causes and Effects (University of Chicago Press, Chicago).

Hall, Robert and John B. Taylor, 1997, Macroeconomics (Norton and Company, New York, NY).

Henry, Peter B., 2000a, Stock market liberalization, economic reform, and emerging market equity prices, Journal of Finance, 55, 529-64.

Henry, Peter B., 2000b, Do stock market liberalizations cause investment booms?, Journal of Financial Economics, 58, 301-34. 
Lucas, Robert E., 1978, Asset prices in an exchange economy, Econometrica, 46, 14291445.

Lucas, Robert E., 2000, Inflation and welfare, Econometrica, 68, 247-74.

Mankiw, N. Gregory, 1997, Macroeconomics (Worth, New York).

Modigliani, Franco, and R.A. Cohn, 1979, Inflation and the stock market, Financial Analyst Journal, 35 (1979), 24-44.

Mussa, Michael, and Miguel Savastan, 1999, The IMF approach to economic Stabilization, NBER Macroeconomics Annual, 14, 79-122.

Okun, Arthur M., 1978, Efficient disinflationary policies, American Economic Review, 68, 348-352.

Phelps, Edmund, 1968, Money-wage dynamics and labor-market equilibrium, Journal of Political Economy, 76, 678-711.

Sargent, Thomas, 1982, The ends of four big inflations, in R.E. Hall, ed.: Inflation: Causes and Effects (University of Chicago Press, Chicago).

Schadler, Susan, 1995, IMF conditionality: Experience under Stand-by and Extended arrangements, IMF Occasional Paper, Number 128.

Schwert, G. William, 1981, The adjustment of stock prices to information about inflation, Journal of Finance, 36, (1), 15-29.

Stulz, René M., Bong-Chan Kho, and Dong Lee, 2000, U.S. banks, crises, and bailouts: From Mexico to LTCM, American Economic Review, 90, (2), 28-31.

Stulz, René M., 1999a, International portfolio flows and security markets, in Martin Feldstein, ed.: International Capital Flows (University of Chicago Press, Chicago).

Stulz, René M., 1999b, Globalization, corporate finance, and the cost of capital, Journal of Applied Corporate Finance, 12, 8-25.

Summers, Lawrence, 1985, On economics and finance, Journal of Finance, 40, (3), 633-635.

Tesar, Linda L., 1999, The role of equity in international capital flows, in Martin Feldstein, ed.: International Capital Flows (University of Chicago Press, Chicago). 
Tesar, Linda L., and Ingrid M. Werner, 1998, The Internationalization of securities markets since the 1987 crash, in Robert E. Litan and Anthony M. Santomero eds.: Brookings Wharton Papers on Financial Services (Brookings Institution Press, Washington).

Tesar, Linda L., and Ingrid M. Werner, 1995, U.S. equity investment in emerging stock markets, World Bank Economic Review, 9, (4), 109-129.

Tobin, James, 1972, Inflation and unemployment, American Economic Review, 62, (1), 1-18.

Végh, Carlos A., 1992, Stopping high inflation: An analytical overview, IMF Staff Papers, 39, 626-695. 
Figure 1. The Stock Market Response to Disinflation Announcements as a Function of Inflation at the Time of the Announcement

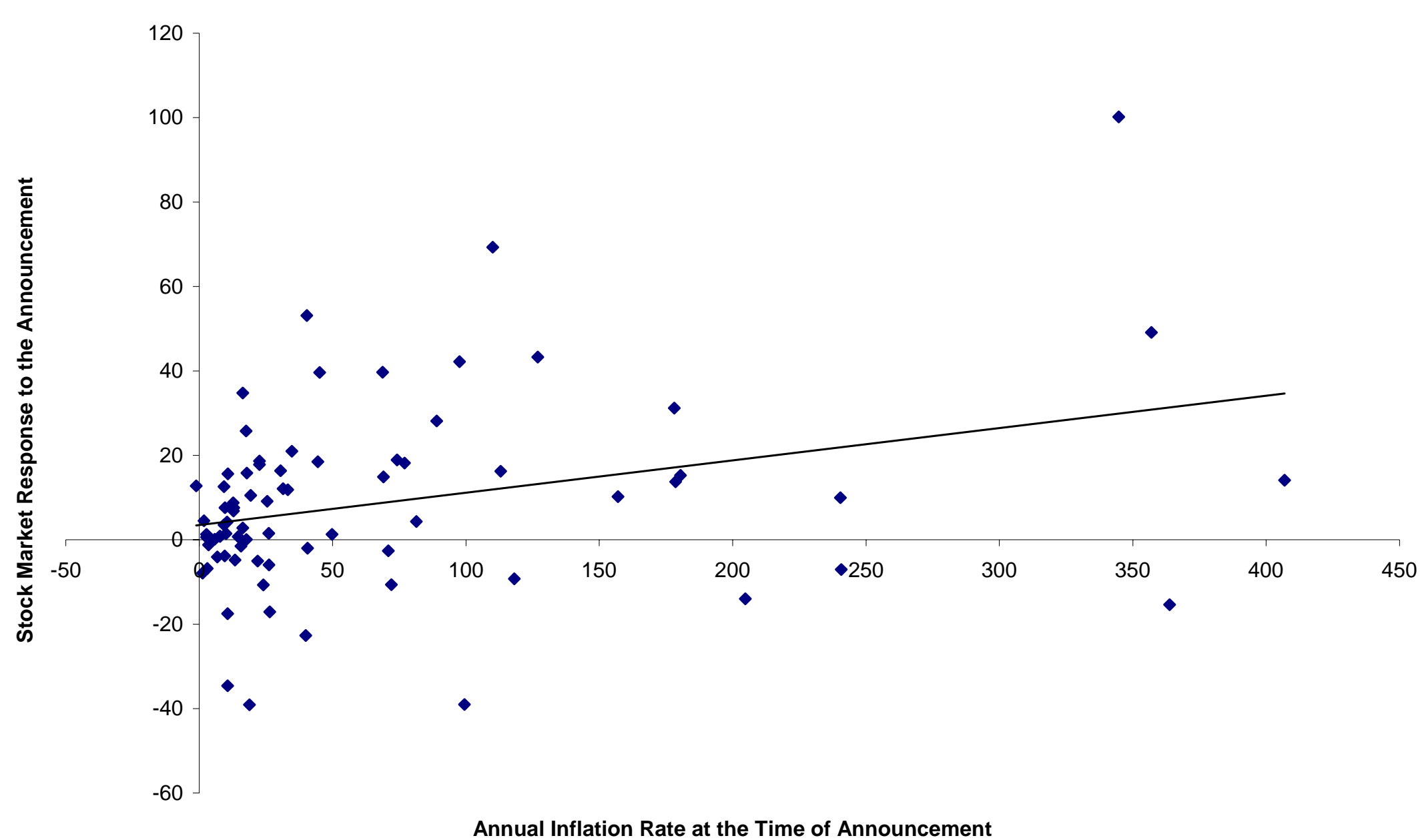


Figure 2. The Stock Market Response to Disinflation Announcements as a Function of Inflation at the Time of Announcement: No Failed Disinflations in Previous 24 months

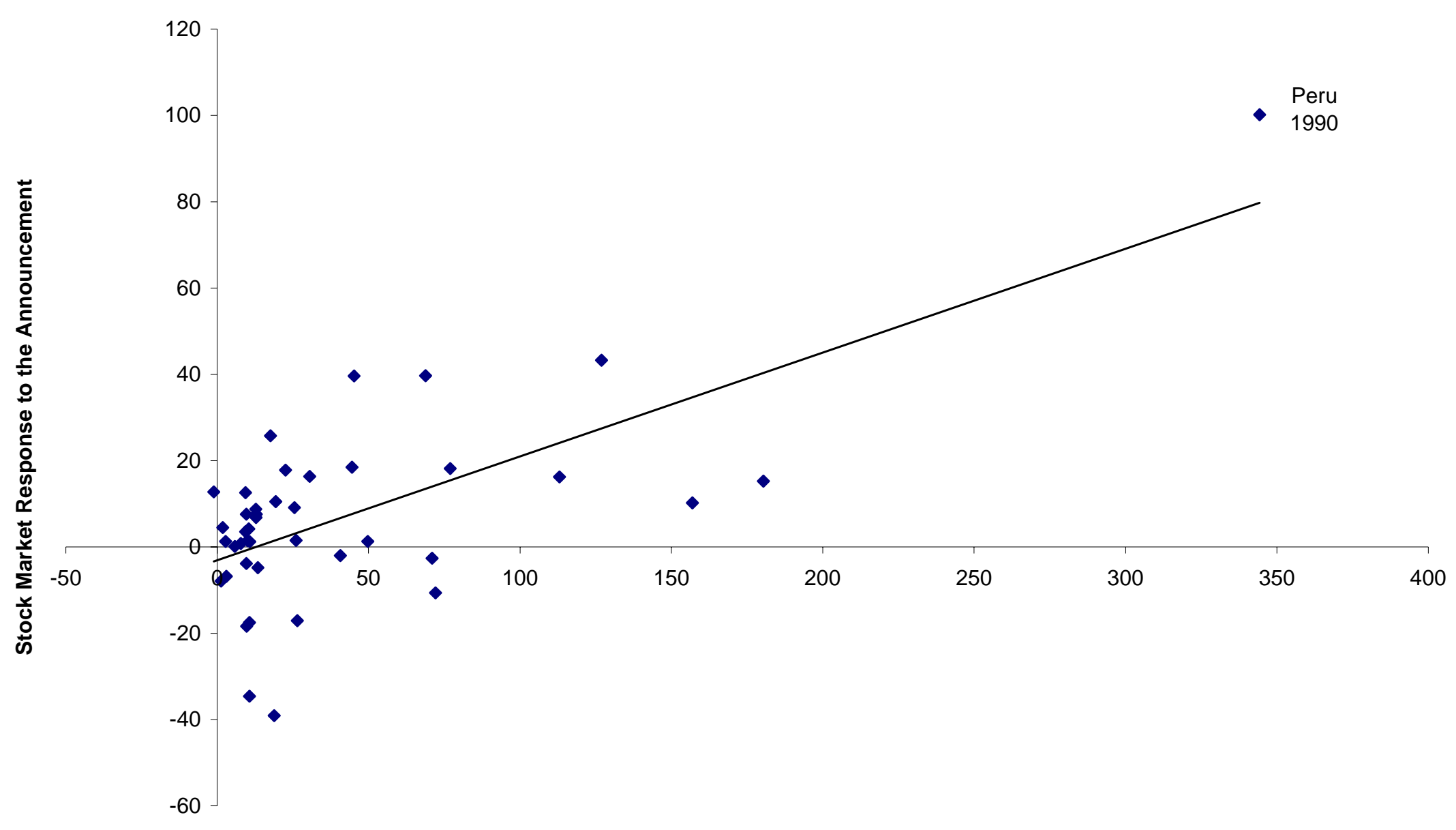

Annual Inflation Rate at the Time of Announcement 


\section{Figure 3. The Stock Market Responses Predict Changes in Future Inflation}

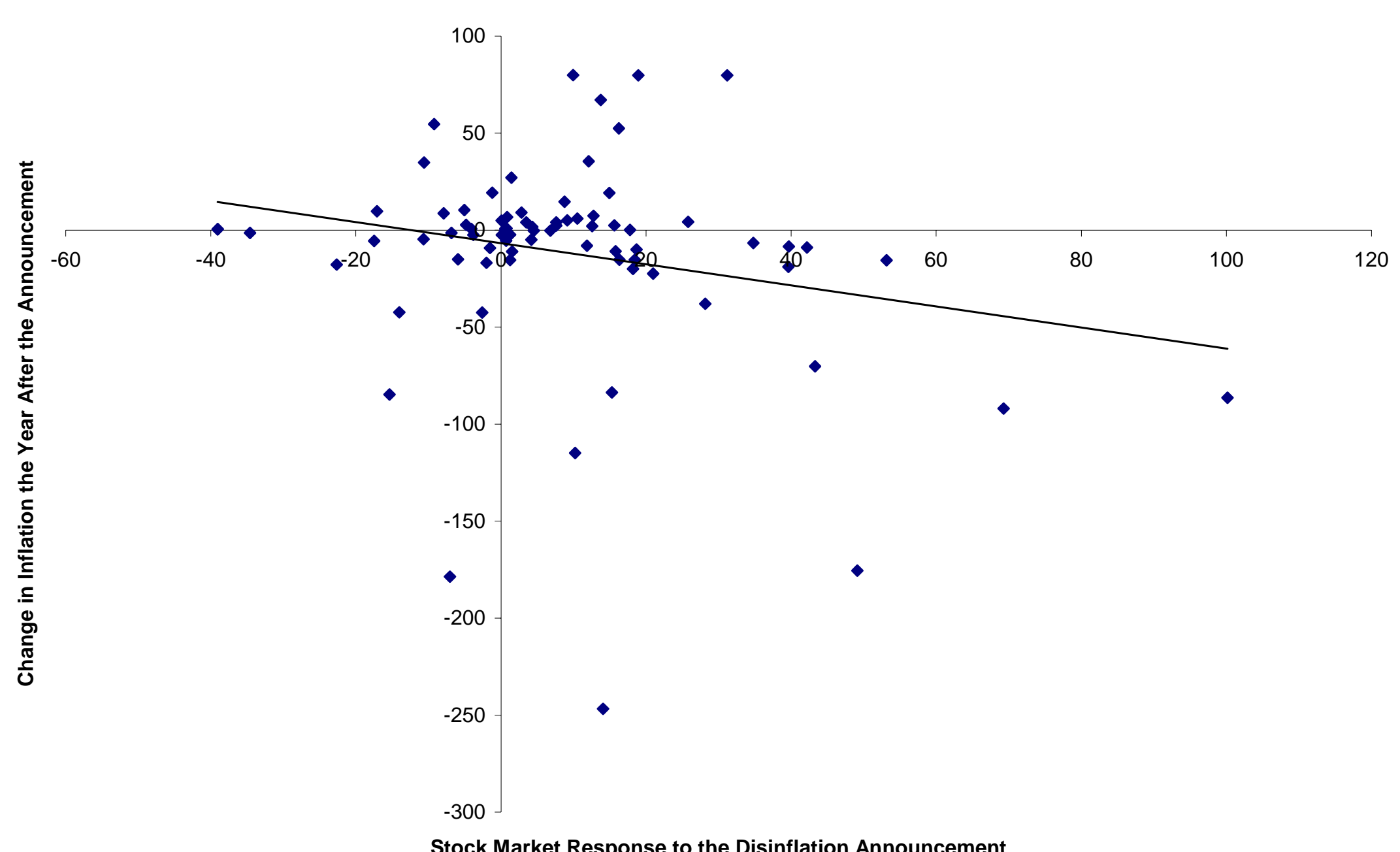


Figure 4. Average Deviation of Real GDP Growth From Country-Specific Sample Mean: All Attempted Stabilizations of High Inflation

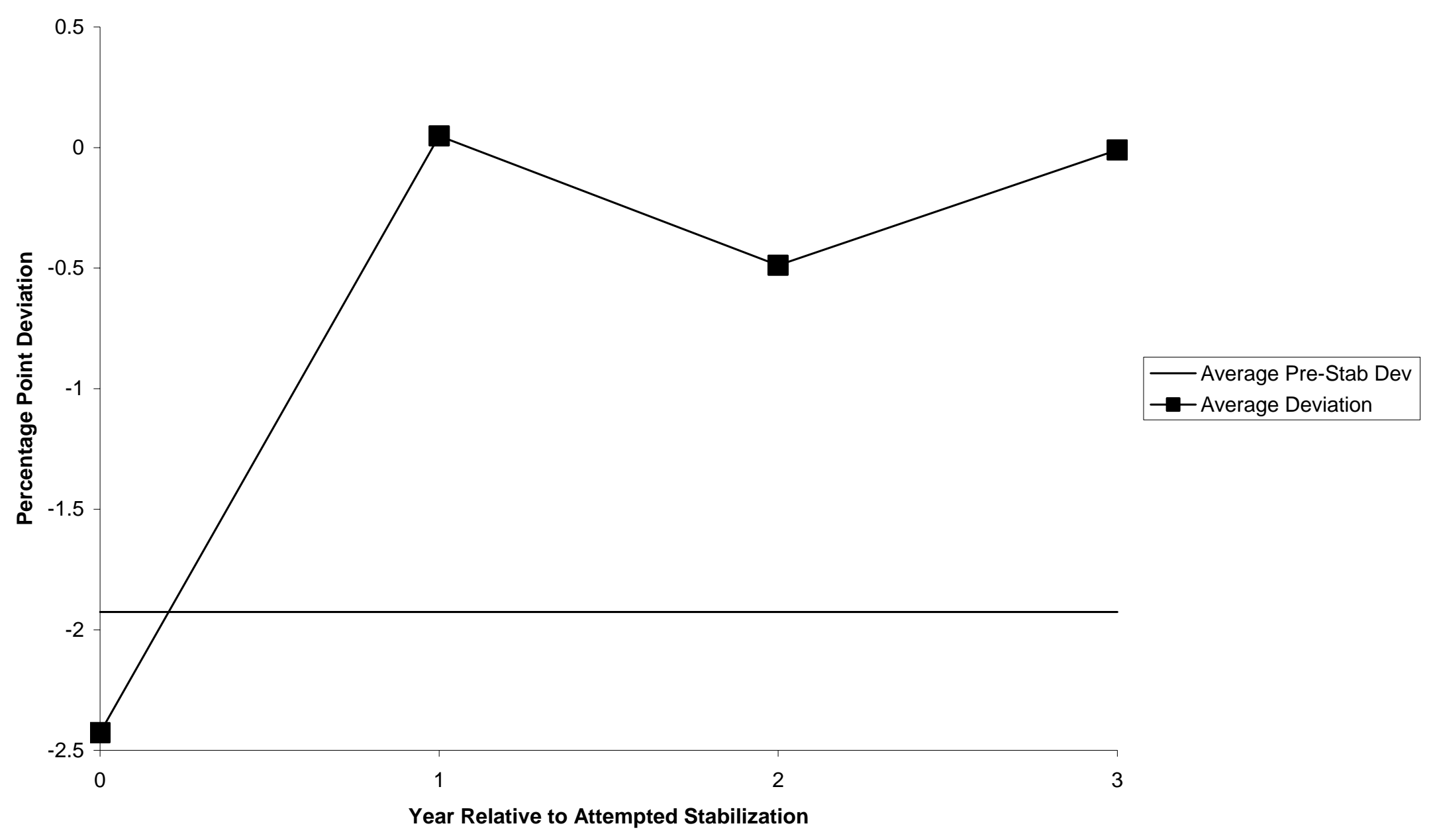


Figure 5. Average Deviation of Real GDP Growth From Country-Specific Sample Mean: All Attempted Stabilizations of Moderate Inflation

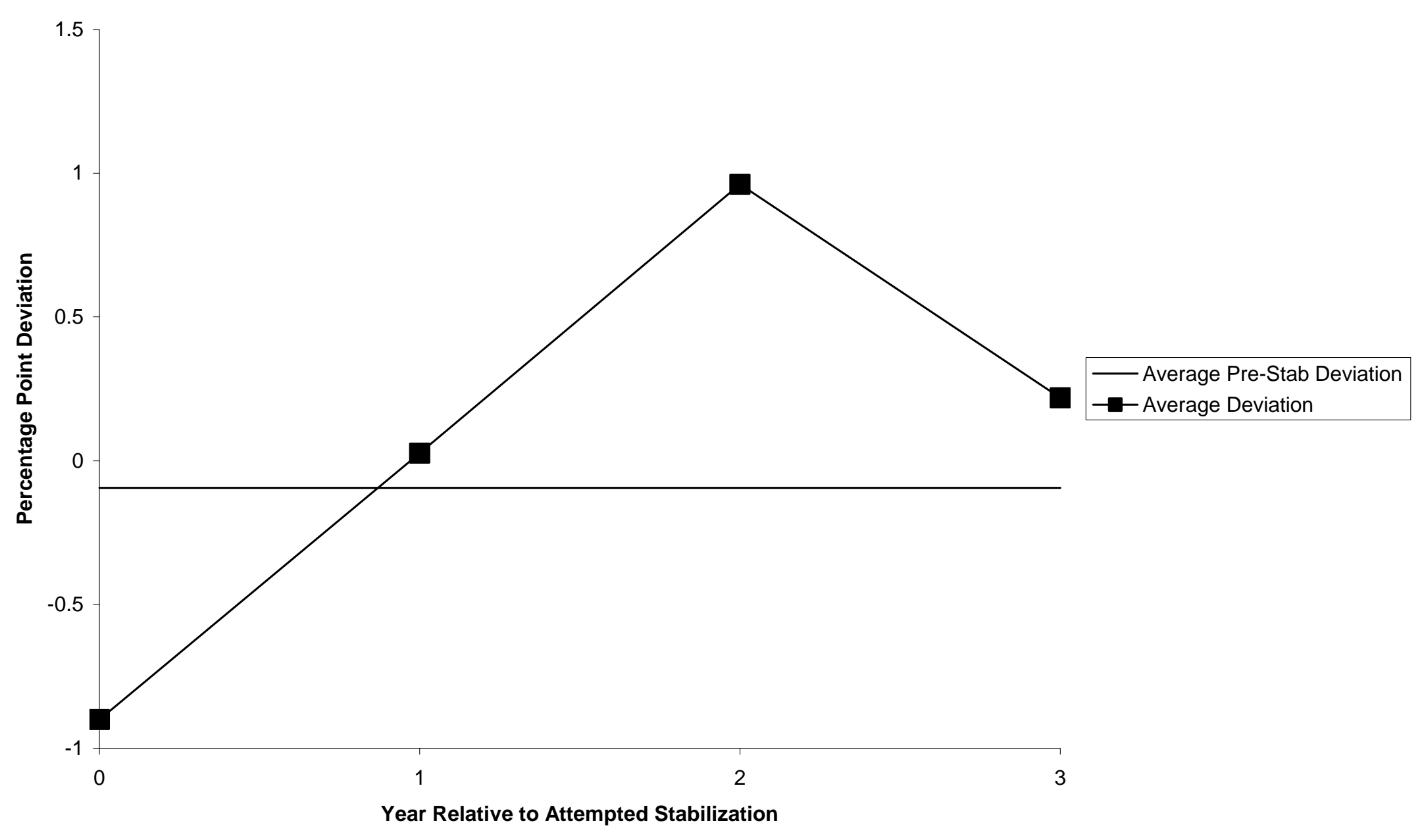


Figure 6. The Stock Market Responses Predict Changes in Future GDP Growth

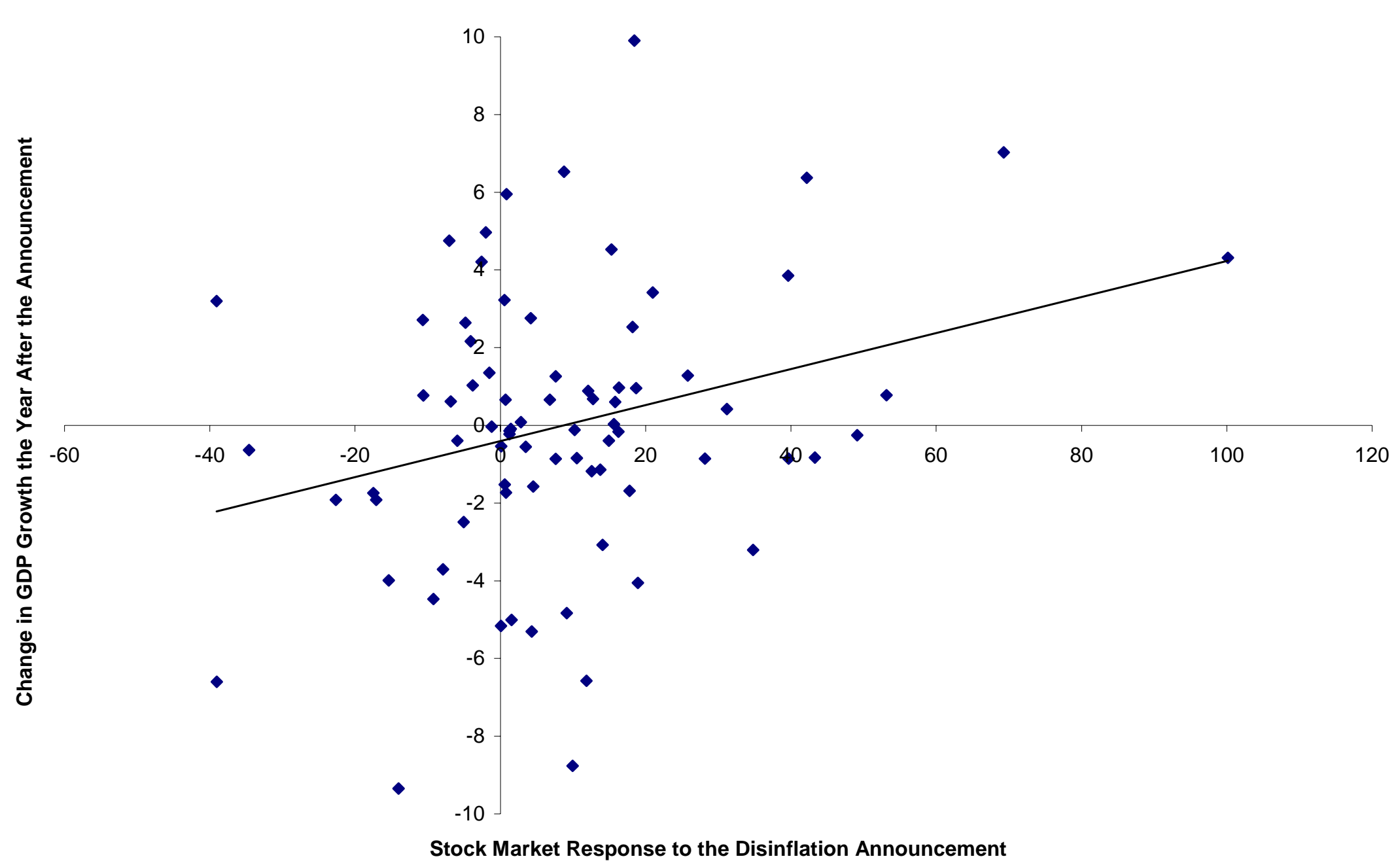


Figure 7. Successful Stabilizations of High Inflation are Associated with Output Booms; Failed Stabilizations of High Inflation Are Not

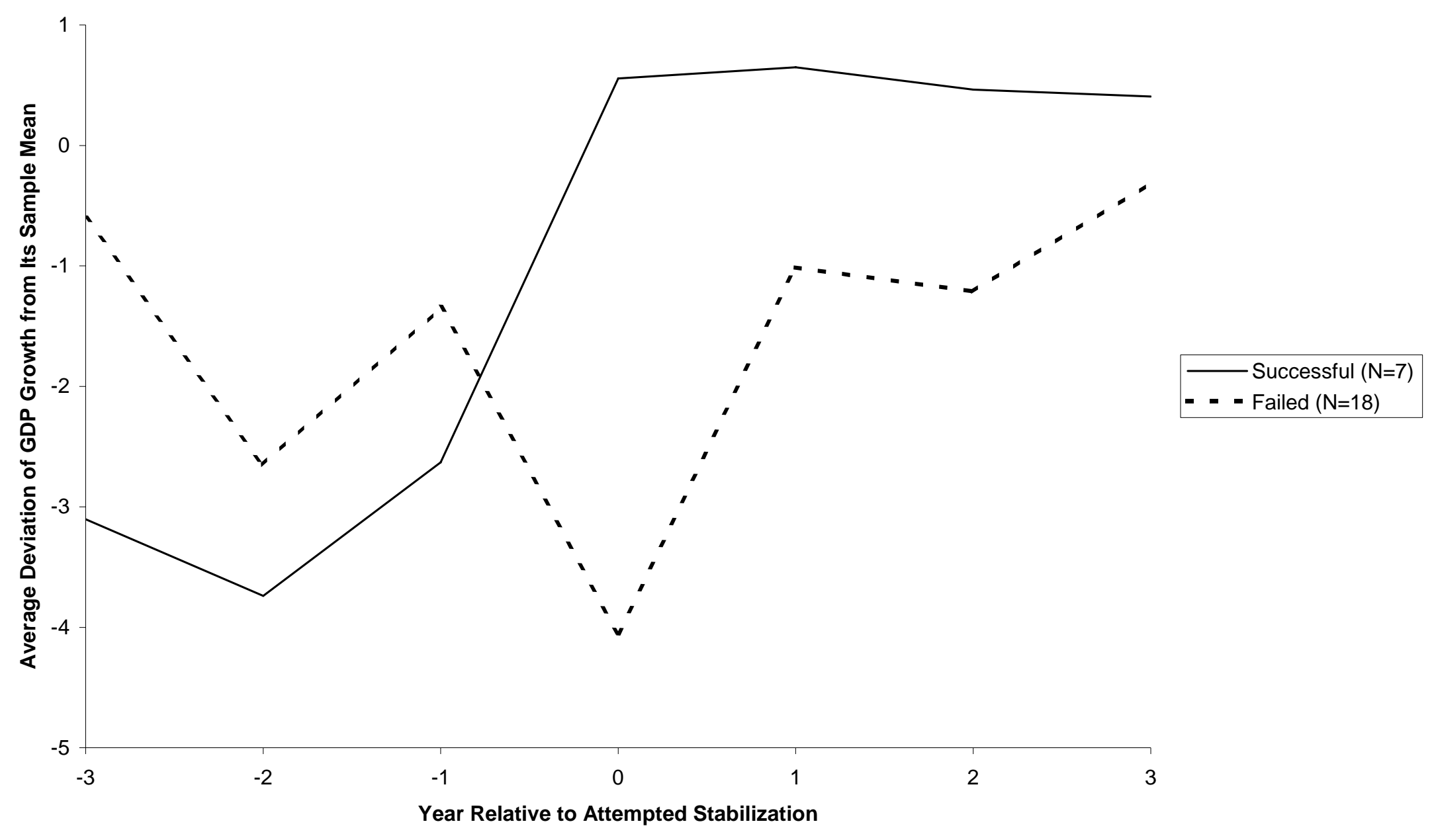


Table I

The Median Stock Price Response to Disinflation Announcements during Episodes of High Inflation Exceeds the Median Stock Price Response to Disinflation Announcements during Episodes of Moderate Inflation

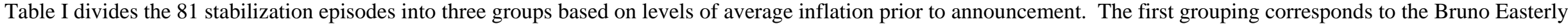

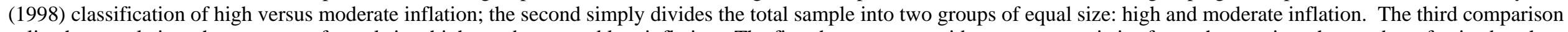

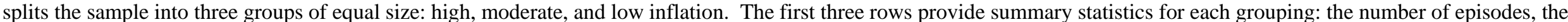

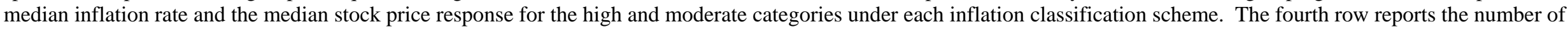

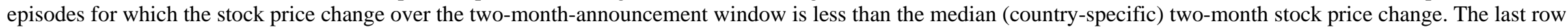

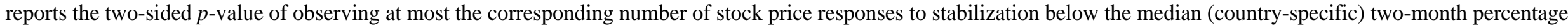
change in the stock price.

Bruno Easterly Classification

High

Number of

Episodes

\section{Median Inflation}

Median Stock

Price Change

Number Negative

$P$-Value
118

16

6

0.01

\section{Two-Way Numerical Split}

High

40

Moderate

25

0.25
11

0.01
41

1

20

0.5
Three-Way Numerical Split

High

Moderate

Low

27

27

116

26

15

11

1

14

0.65 
Table II

The Average Stock Price Response to Disinflation Announcements during Episodes of High Inflation Exceeds the Average Stock

Price Response to Disinflation Announcements during Episodes of Moderate Inflation

The left-hand-side variable is real, dollar-denominated stock returns. The estimation procedure is feasible generalized least squares. Heteroscedastic-consistent standard errors are given in parentheses. The classification of high and moderate inflation follows Bruno and Easterly (1998) as described in the text. The column labeled Month $[0,+1]$ presents estimates of HIGH and MODERATE using the two-month announcement window described in the text. The column labeled Month [0] presents estimates of HIGH and MODERATE using the one-month announcement window described in the text. The first row presents estimates of HIGH and MODERATE from the benchmark specification using a World stock return index. Row 2 presents estimates of HIGH and MODERATE from a specification that uses U.S. stock returns in place of a World stock return index in equation (3). Row 3 presents estimates that use the IFC Emerging Market index. Row 4 presents estimates that use all three sets of returns simultaneously. Row 5 presents estimates of HIGH and MODERATE based on simple mean-adjusted abnormal returns. Row 6 presents estimates using a statistical model, which allows for country-specific intercept terms. The column labeled P-Value of HIGH>MODERATE shows the p-value for a test that the coefficient on HIGH is significantly larger than the coefficient on MODERATE. The symbols ***, **, and * denote statistical significance at the one percent, five percent, and 10 percent confidence levels, respectively.

Panel A: Month $[0,+1]$ Estimates

\section{HIGH}

\section{MODERATE}

P-Value of

HIGH>

MODERATE
Panel B: Month [0] Estimates

$\begin{array}{ll}\text { HIGH MODERATE } & \text { P-Value of } \\ & \text { HIGH> } \\ & \text { MODERATE }\end{array}$

Controls
$0.121^{* * *}$
0.001

(0.023)

$(0.01)$

0.00

0.00

0.001
$(0.01)$

(0.023)

0.005

(0.026)

(0.012)

0.00

0.006

(0.026)

(0.012)

0.001

Constant-

$0.122 * * *$

$(0.01)$

Mean Return

$(0.023)$

0.001

Country-

$0.122 * * *$

(0.01)

0.00

Specific

(0.001)
Mean Return
$0.126 * * *$

(0.032)

$-0.004$

(0.012)

$0.121^{* * *}$

(0.032)

$-0.006$

(0.012)

$0.081^{* *}$

0.008

(0.037)

(0.02)

$\begin{array}{lr}0.080 * * & 0.006 \\ (0.037) & (0.02)\end{array}$

$0.124 * * * \quad-0.003$

(0.032) (0.01)

$0.122 * * * \quad-0.003$

0.00

(0.033) (0.01) 


\section{Table III}

The Stock Market Falls in Anticipation of Disinflation Announcements Made During Episodes of Moderate Inflation

The abbreviation AR stands for abnormal return. The abnormal return for month [ $\mathrm{n}$ ] is defined as the coefficient on a dummy variable that takes on the value 1 in nth

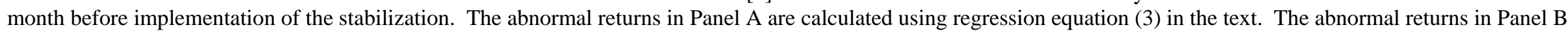
are generated using regression equation (4) in the text.

\begin{tabular}{|c|c|c|c|c|c|c|c|c|}
\hline \multirow{3}{*}{$\begin{array}{l}\text { Month } \\
\text { Relative to } \\
\text { Stabilization }\end{array}$} & \multicolumn{4}{|c|}{ Panel A: World-Return Model } & \multicolumn{4}{|c|}{ Panel B: Constant-Mean-Return Model } \\
\hline & \multicolumn{2}{|c|}{ High Inflation } & \multicolumn{2}{|c|}{ Moderate Inflation } & \multicolumn{2}{|c|}{ High Inflation } & \multicolumn{2}{|c|}{ Moderate Inflation } \\
\hline & AR & CAR & $\mathrm{AR}$ & CAR & AR & CAR & AR & CAR \\
\hline-12 & -.036 & -.036 & -.008 & -.008 & -.038 & -.038 & -.010 & -.010 \\
\hline-11 & -.033 & -.069 & -.018 & -.026 & -.033 & -.070 & -.016 & -.026 \\
\hline-10 & -.053 & -.122 & -.012 & -.038 & -.050 & -.121 & -.014 & -.040 \\
\hline-9 & .007 & -.116 & -.010 & -.048 & .002 & -.119 & -.012 & -.052 \\
\hline-8 & -.005 & -.121 & -.007 & -.054 & -.003 & -.122 & -.007 & -.058 \\
\hline-7 & .027 & -.094 & .011 & -.043 & .028 & -.094 & .012 & -.047 \\
\hline-6 & .042 & -.052 & -.020 & -.063 & .043 & -.051 & -.019 & -.065 \\
\hline-5 & .035 & -.018 & -.023 & -.086 & .037 & -.014 & -.024 & -.090 \\
\hline-4 & -.005 & -.022 & -.030 & -.116 & -.004 & -.018 & -.030 & -.120 \\
\hline-3 & .057 & .035 & -.026 & -.142 & .060 & .041 & -.026 & -.146 \\
\hline-2 & -.028 & .006 & -.008 & -.150 & -.025 & .016 & -.007 & -.153 \\
\hline-1 & -.030 & -.023 & -.014 & -.163 & -.032 & -.016 & -.013 & -.166 \\
\hline 0 & .088 & .064 & -.008 & -.172 & .085 & .069 & -.007 & -.173 \\
\hline 1 & .126 & .190 & .011 & -.161 & .127 & .196 & .011 & -.162 \\
\hline
\end{tabular}




\section{Table IV}

The Average Stock Market Response to Announcements of Exchange-Rate-Based Stabilizations (ERBS) Is Not Significantly Larger Than the Average Stock Market Response to Non-Exchange-Rate Based Stabilizations (NONERBS)

The left-hand-side variable is real, dollar-denominated stock returns. The estimation procedure is feasible generalized least squares. Heteroscedasticconsistent standard errors are given in parentheses. The column labeled Month $[0,+1]$ presents estimates of the stock market response to exchange-ratebased and non-exchange-rate-based stabilizations of high inflation using the two-month announcement window described in the text. The column labeled Month [0] presents estimates of ERBS and NONERBS using the one-month announcement window described in the text. The first row presents estimates using the benchmark specification using a World stock return index. Row 2 presents estimates of ERBS and NONERBS from a specification that uses U.S. stock returns in place of the World stock return index in equation (5). Row 3 presents estimates of ERBS and NONERBS from a specification that uses the IFC Emerging Market index. Row 4 presents estimates of ERBS and NONERBS from a specification that uses all three sets of returns simultaneously. Row 5 presents estimates based on simple mean-adjusted abnormal returns. Row 6 presents estimates using a statistical model, which allows for country-specific intercept terms. The column labeled P-Value of ERBS>NONERBS shows the p-value for a test that the stock market response to exchange-rate-based stabilizations of high inflation is significantly different from the stock market response to non-exchange-rate-based stabilizations of high inflation. The symbols $* * *, * *$, and $*$ denote statistical significance at the one percent, five percent, and 10 percent confidence levels, respectively.

Panel A: Month $[0,+1]$ Estimates

\section{Non}

\begin{tabular}{ccc} 
& $\begin{array}{c}\text { Exchange- } \\
\text { Rate-Based } \\
\text { Stabilization }\end{array}$ & $\begin{array}{c}\text { Exchange- } \\
\text { Rate-Based } \\
\text { Stabilization }\end{array}$ \\
\hline World & $0.152^{* * *}$ & $0.102^{* * *}$ \\
$(0.037)$ & $(0.029)$
\end{tabular}

U.S.

$\begin{array}{ll}0.148 * * * & 0.100 * * * \\ (0.037) & (0.029)\end{array}$

LDC

$0.105^{* * *}$

$(0.04)$

All

$\begin{array}{ll}0.122 * * * & 0.105^{* * *} \\ (0.034) & (0.04)\end{array}$

Constant-

$0.152 * * *$

Mean

(0.037)

Country-

$0.150 * * *$

(0.037)
$0.121 * * *$

(0.034)

$0.102 * * *$

\section{P-Value of \\ ERBS $>N O N$ \\ ERBS}

0.28

0.31

0.77

0.75

0.29

$0.103^{* * *}$

(0.029)
Panel B: Month [0] Estimates

Non

Exchange- Exchange-

Rate-Based

Rate-Based

Stabilization

Stabilization

P-Value of

ERBS $>N O N$

ERBS

$0.154 * * * \quad 0.109 * * *$

(0.041)

(0.052)

$0.106^{* * *}$

$0.146 * * *$

(0.041)

0.55

(0.052)

$0.113^{* *}$

0.039

(0.049)

0.308

(0.055)

$0.116 * *$

(0.055)

(0.049)

$\begin{array}{ll}0.151^{* * *} & 0.108^{* * *} \\ (0.052) & (0.041\end{array}$

$0.149 * * * \quad 0.106 * * *$ (0.052)

(0.042)




\section{APPENDIX}

Table A1 lists the information used to identify the disinflation announcements referred to in the text.

\section{Table A1}

\section{Characteristics of Inflation Stabilization Programs in Emerging Economies with Stock Markets}

Each panel of Table A1 corresponds to a given country. Column 1 identifies the country to which each panel applies. Column 2 enumerates the month and year of all the disinflation announcements that occurred in each of the countries during the sample period (the period for which stock market data are available for each country). Columns 3 and 4 indicate how the stabilization dates in Column 2 were identified. A "Yes" in a given row of column 3 indicates that the date in the corresponding row of Column 1 is the starting date for a Calvo and Végh (1998) stabilization episode. A "Yes" in a given row of column 4 indicates that an official agreement was signed with the IMF. The type of IMF agreement is given in parentheses. SB denotes a Stand-By agreement and EFF denotes an Extended Fund Facility agreement. See Schadler et al. (1995) for a detailed discussion of these agreements. Column 5 indicates the level of inflation at the time the program was announced. A "Yes" in Column 5 indicates that the country was experiencing high inflation. A "Yes" in Column 6 indicates that there was a stabilization program in the previous 24 months. A "Yes" in Column 7 indicates that there was a stabilization program in the subsequent 24 months. A "Yes" in Column 8 indicates that the stabilization program was successful. In keeping with the spirit of the Bruno and Easterly (1996) definition of high inflation, a stabilization program implemented in the midst of high inflation is defined as successful if (prior to the announcement of another stabilization program) annualized monthly inflation falls below 40 percent and remains below 40 percent for two or more years. In accordance with Dornbusch and Fischer (1993) and Burton and Fischer (1998), a stabilization program announced in the midst of moderate inflation is defined as successful if annualized monthly inflation falls below 10 percent and remains below 10 percent for two or more years. A "Yes" in Column 9 indicates that the stabilization program was exchange-rate-based according to Calvo and Végh (1998) and Fischer et al. (2002).

\begin{tabular}{|c|c|c|c|c|c|c|c|c|}
\hline Country & $\begin{array}{c}\text { Date of } \\
\text { Stabilization } \\
\text { Program }\end{array}$ & Episodic & $\begin{array}{c}\text { IMF } \\
\text { Agreement? }\end{array}$ & $\begin{array}{c}\text { High } \\
\text { Inflation } \\
\text { Crisis? }\end{array}$ & $\begin{array}{l}\text { Stabilization } \\
\text { in the } \\
\text { Previous } 24 \\
\text { Months? }\end{array}$ & $\begin{array}{l}\text { Stabilization } \\
\text { in the } \\
\text { Following } \\
24 \text { Months? }\end{array}$ & $\begin{array}{l}\text { Stabilization } \\
\text { Successful? }\end{array}$ & $\begin{array}{c}\text { Exchange } \\
\text { Rate } \\
\text { Based? }\end{array}$ \\
\hline
\end{tabular}

Panel A:

Argentina

Aug 1976

Sept 1977

Dec 1978

Jun 1983

Dec 1984

Jun 1985

Jul 1987

Nov 1989

Apr 1991

Mar 1992

$\begin{array}{cccc}\text { Yes }(\mathrm{SB}) & \text { Yes } & & \text { Yes } \\ \text { Yes }(\mathrm{SB}) & \text { Yes } & \text { Yes } & \text { Yes } \\ & \text { Yes } & \text { Yes } & \\ \text { Yes }(\mathrm{SB}) & \text { Yes } & & \text { Yes } \\ \text { Yes (SB) } & \text { Yes } & \text { Yes } & \text { Yes } \\ & \text { Yes } & \text { Yes } & \\ \text { Yes (SB) } & \text { Yes } & \text { Yes } & \\ & \text { Yes } & \text { Yes } & \text { Yes } \\ \text { Yes (SB) } & \text { Yes } & \text { Yes } & \\ \text { Yes (EFF) } & & & \end{array}$

Yes (Austral)

Yes (Bonex)

Yes

(Convertibility)

Yes (EFF)
Yes

Yes 


\begin{tabular}{|c|c|c|c|c|c|c|c|c|}
\hline Country & $\begin{array}{c}\text { Date of } \\
\text { Stabilization } \\
\text { Program }\end{array}$ & Episodic & $\begin{array}{c}\text { IMF } \\
\text { Agreement? }\end{array}$ & $\begin{array}{c}\text { High } \\
\text { Inflation } \\
\text { Crisis? }\end{array}$ & $\begin{array}{l}\text { Stabilization } \\
\text { in the } \\
\text { Previous } 24 \\
\text { Months? }\end{array}$ & $\begin{array}{l}\text { Stabilization } \\
\text { in the } \\
\text { Following } \\
24 \text { Months? }\end{array}$ & $\begin{array}{c}\text { Stabilization } \\
\text { Successful? }\end{array}$ & $\begin{array}{c}\text { Exchange } \\
\text { Rate } \\
\text { Based? }\end{array}$ \\
\hline \multicolumn{9}{|l|}{$\begin{array}{l}\text { Panel B: } \\
\text { Brazil }\end{array}$} \\
\hline & Mar 1983 & & Yes (SB) & Yes & & & & \\
\hline & Feb 1986 & Yes (Cruzado) & & Yes & & Yes & & Yes \\
\hline & Jul 1987 & Yes (Bresser) & & Yes & Yes & Yes & & \\
\hline & Aug 1988 & & Yes (SB) & Yes & Yes & Yes & & \\
\hline & Jan 1989 & Yes (Summer) & & Yes & Yes & Yes & & \\
\hline & Apr 1990 & Yes (Collor) & & Yes & Yes & Yes & & \\
\hline & Jan 1992 & & Yes (SB) & Yes & Yes & & & \\
\hline & Mar 1994 & Yes (Real) & & Yes & Yes & & Yes & Yes \\
\hline \multicolumn{9}{|l|}{$\begin{array}{l}\text { Panel C: } \\
\text { Chile }\end{array}$} \\
\hline & Feb 1978 & Yes (Tablita) & & Yes & & & Yes & Yes \\
\hline & Jan 1983 & & Yes (SB) & & & & & \\
\hline & Aug 1985 & & Yes (EFF) & & & & & \\
\hline & Nov 1989 & & Yes (SB) & & & & Yes & \\
\hline \multicolumn{9}{|l|}{$\begin{array}{l}\text { Panel D: } \\
\text { Egypt }\end{array}$} \\
\hline & May 1991 & & Yes (SB) & & & & Yes & \\
\hline
\end{tabular}


Table A1 - Continued

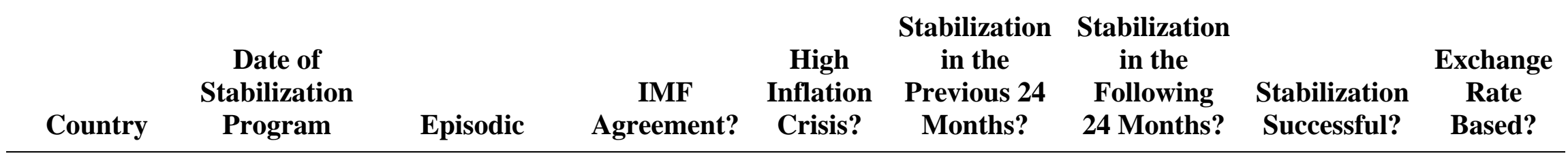

Panel E:

India

Nov 1981
Jan 1991
Oct 1991

Panel F:

Indonesia

Panel G:

Israel

Jul $1985 \quad$ Yes

Yes (EFF)

Yes (SB)

Yes (SB)

Yes

\section{Yes}

May 1973 


\begin{tabular}{|c|c|c|c|c|c|c|c|c|}
\hline Country & $\begin{array}{c}\text { Date of } \\
\text { Stabilization } \\
\text { Program }\end{array}$ & Episodic & $\begin{array}{c}\text { IMF } \\
\text { Agreement? }\end{array}$ & $\begin{array}{c}\text { High } \\
\text { Inflation } \\
\text { Crisis? }\end{array}$ & $\begin{array}{l}\text { Stabilization } \\
\text { in the } \\
\text { Previous } 24 \\
\text { Months? }\end{array}$ & $\begin{array}{l}\text { Stabilization } \\
\text { in the } \\
\text { Following } \\
24 \text { Months? }\end{array}$ & $\begin{array}{l}\text { Stabilization } \\
\text { Successful? }\end{array}$ & $\begin{array}{c}\text { Exchange } \\
\text { Rate } \\
\text { Based? }\end{array}$ \\
\hline \multicolumn{9}{|l|}{$\begin{array}{l}\text { Panel H: } \\
\text { Jamaica }\end{array}$} \\
\hline & Aug 1977 & & Yes (SB) & & & Yes & & \\
\hline & Jun 1978 & & Yes (EFF) & & Yes & Yes & & \\
\hline & Jun 1979 & & Yes (EFF) & & Yes & Yes & & \\
\hline & Apr 1981 & & Yes (EFF) & & Yes & & & \\
\hline & Jun 1984 & & Yes (SB) & & Yes & Yes & & \\
\hline & Jul 1985 & & Yes (SB) & & Yes & Yes & & \\
\hline & Mar 1987 & & Yes (SB) & & Yes & Yes & & \\
\hline & Sept 1988 & & Yes (SB) & & Yes & Yes & & \\
\hline & Mar 1990 & & Yes (SB) & & Yes & Yes & & \\
\hline & Jun 1991 & & Yes (SB) & & Yes & Yes & & \\
\hline & Dec 1992 & & Yes (SB) & Yes & Yes & & Yes & \\
\hline \multicolumn{9}{|l|}{$\begin{array}{l}\text { Panel I: } \\
\text { Jordan }\end{array}$} \\
\hline & Jul 1989 & & Yes (SB) & & & & & \\
\hline & Feb 1992 & & Yes (SB) & & & & & \\
\hline & May 1994 & & Yes (EFF) & & & & & \\
\hline
\end{tabular}




\begin{tabular}{|c|c|c|c|c|c|c|c|c|}
\hline Country & $\begin{array}{c}\text { Date of } \\
\text { Stabilization } \\
\text { Program }\end{array}$ & Episodic & $\begin{array}{c}\text { IMF } \\
\text { Agreement? }\end{array}$ & $\begin{array}{c}\text { High } \\
\text { Inflation } \\
\text { Crisis? }\end{array}$ & $\begin{array}{l}\text { Stabilization } \\
\text { in the } \\
\text { Previous } 24 \\
\text { Months? }\end{array}$ & $\begin{array}{l}\text { Stabilization } \\
\text { in the } \\
\text { Following } \\
\text { 24 Months? }\end{array}$ & $\begin{array}{l}\text { Stabilization } \\
\text { Successful? }\end{array}$ & $\begin{array}{c}\text { Exchange } \\
\text { Rate } \\
\text { Based? }\end{array}$ \\
\hline \multicolumn{9}{|l|}{$\begin{array}{l}\text { Panel J: } \\
\text { Kenya }\end{array}$} \\
\hline & May 1993 & & Yes & & & & Yes & \\
\hline \multicolumn{9}{|l|}{$\begin{array}{l}\text { Panel K: } \\
\text { Korea }\end{array}$} \\
\hline & May 1977 & & Yes (SB) & & & & & \\
\hline & Mar 1980 & & Yes (SB) & & & Yes & Yes & \\
\hline & Feb 1981 & & Yes (SB) & & Yes & & & \\
\hline & Jul 1983 & & Yes (SB) & & & Yes & & \\
\hline & Jul 1985 & & Yes (SB) & & Yes & & & \\
\hline \multicolumn{9}{|l|}{$\begin{array}{l}\text { Panel L: } \\
\text { Mexico }\end{array}$} \\
\hline & Jan 1977 & Yes & Yes (EFF) & & Yes & & & \\
\hline & Jan 1983 & & Yes (EFF) & & & & & \\
\hline & Nov 1986 & & Yes (SB) & Yes & & Yes & & \\
\hline & Dec 1987 & Yes (Pacto) & & Yes & Yes & Yes & Yes & Yes \\
\hline & May 1989 & & Yes (EFF) & & & & & \\
\hline
\end{tabular}




\begin{tabular}{|c|c|c|c|c|c|c|c|c|}
\hline Country & $\begin{array}{c}\text { Date of } \\
\text { Stabilization } \\
\text { Program }\end{array}$ & Episodic & $\begin{array}{c}\text { IMF } \\
\text { Agreement? }\end{array}$ & $\begin{array}{c}\text { High } \\
\text { Inflation } \\
\text { Crisis? }\end{array}$ & $\begin{array}{l}\text { Stabilization } \\
\text { in the } \\
\text { Previous } 24 \\
\text { Months? }\end{array}$ & $\begin{array}{l}\text { Stabilization } \\
\text { in the } \\
\text { Following } \\
24 \text { Months? }\end{array}$ & $\begin{array}{l}\text { Stabilization } \\
\text { Successful? }\end{array}$ & $\begin{array}{c}\text { Exchange } \\
\text { Rate } \\
\text { Based? }\end{array}$ \\
\hline \multicolumn{9}{|l|}{$\begin{array}{l}\text { Panel M: } \\
\text { Nigeria }\end{array}$} \\
\hline & Jan 1987 & & Yes (SB) & & & & & \\
\hline & Feb 1989 & & Yes (SB) & & & Yes & & \\
\hline & Jan 1991 & & Yes (SB) & & Yes & & & \\
\hline \multicolumn{9}{|l|}{$\begin{array}{l}\text { Panel N: } \\
\text { Pakistan }\end{array}$} \\
\hline & Mar 1977 & & Yes (SB) & & & & & \\
\hline & Nov 1980 & & Yes (EFF) & & & Yes & & \\
\hline & Dec 1981 & & Yes (EFF) & & Yes & & & \\
\hline & Dec 1988 & & Yes (SB) & & & & & \\
\hline & Sept 1993 & & Yes (SB) & & & Yes & & \\
\hline & Feb 1994 & & Yes (EFF) & & Yes & & & \\
\hline
\end{tabular}

Panel O:

Peru

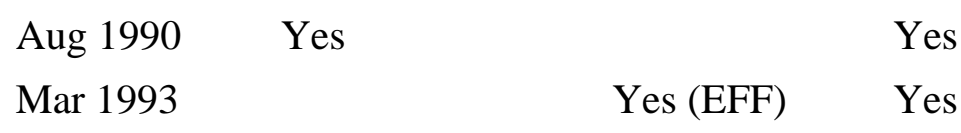

Yes 


\begin{tabular}{|c|c|c|c|c|c|c|c|c|}
\hline Country & $\begin{array}{c}\text { Date of } \\
\text { Stabilization } \\
\text { Program }\end{array}$ & Episodic & $\begin{array}{c}\text { IMF } \\
\text { Agreement? }\end{array}$ & $\begin{array}{c}\text { High } \\
\text { Inflation } \\
\text { Crisis? }\end{array}$ & $\begin{array}{l}\text { Stabilization } \\
\text { in the } \\
\text { Previous } 24 \\
\text { Months? }\end{array}$ & $\begin{array}{c}\text { Stabilization } \\
\text { in the } \\
\text { Following } \\
24 \text { Months? }\end{array}$ & $\begin{array}{l}\text { Stabilization } \\
\text { Successful? }\end{array}$ & $\begin{array}{c}\text { Exchange } \\
\text { Rate } \\
\text { Based? }\end{array}$ \\
\hline \multicolumn{9}{|l|}{$\begin{array}{l}\text { Panel P: } \\
\text { Philippines }\end{array}$} \\
\hline & Oct 1986 & & Yes (SB) & & & & & \\
\hline & May 1989 & & Yes (EFF) & & & Yes & & \\
\hline & Feb 1991 & & Yes (SB) & & Yes & & & \\
\hline & Jun 1994 & & Yes (EFF) & & & & & \\
\hline \multicolumn{9}{|l|}{$\begin{array}{l}\text { Panel Q: } \\
\text { S. Africa: }\end{array}$} \\
\hline & Jan 1976 & & Yes (SB) & & & Yes & & \\
\hline & Aug 1976 & & Yes (SB) & & Yes & & & \\
\hline & Nov 1982 & & Yes (SB) & & & & & \\
\hline \multicolumn{9}{|l|}{$\begin{array}{l}\text { Panel R: } \\
\text { Thailand }\end{array}$} \\
\hline & Jul 1978 & & Yes (SB) & & & & & \\
\hline & Jun 1981 & & Yes (SB) & & & Yes & & \\
\hline & Nov 1982 & & Yes (SB) & & Yes & & & \\
\hline & Jun 1985 & & Yes (SB) & & & & & \\
\hline
\end{tabular}




\begin{tabular}{|c|c|c|c|c|c|c|c|c|}
\hline Country & $\begin{array}{c}\text { Date of } \\
\text { Stabilization } \\
\text { Program }\end{array}$ & Episodic & $\begin{array}{c}\text { IMF } \\
\text { Agreement? }\end{array}$ & $\begin{array}{c}\text { High } \\
\text { Inflation } \\
\text { Crisis? }\end{array}$ & $\begin{array}{c}\text { Stabilization } \\
\text { in the } \\
\text { Previous } 24 \\
\text { Months? }\end{array}$ & $\begin{array}{c}\text { Stabilization } \\
\text { in the } \\
\text { Following } \\
24 \text { Months? }\end{array}$ & $\begin{array}{c}\text { Stabilization } \\
\text { Successful? }\end{array}$ & $\begin{array}{c}\text { Exchange } \\
\text { Rate } \\
\text { Based? }\end{array}$ \\
\hline \multicolumn{9}{|l|}{$\begin{array}{l}\text { Panel S: } \\
\text { Turkey }\end{array}$} \\
\hline & Jul 1994 & & Yes (SB) & Yes & & & & \\
\hline \multicolumn{9}{|l|}{$\begin{array}{l}\text { Panel T: } \\
\text { Venezuela }\end{array}$} \\
\hline & Jun 1989 & & Yes (EFF) & & & & & \\
\hline \multicolumn{9}{|l|}{$\begin{array}{l}\text { Panel U: } \\
\text { Zimbabwe }\end{array}$} \\
\hline & Apr 1981 & & Yes (SB) & & & Yes & & \\
\hline & Mar 1983 & & Yes (SB) & & Yes & & & \\
\hline & Jan 1992 & & Yes (EFF) & & & Yes & & \\
\hline & Sept 1992 & & Yes (EFF) & & Yes & & & \\
\hline $\begin{array}{l}\text { Total } \\
\text { Number }\end{array}$ & 81 & 14 & 69 & 25 & 42 & 47 & 12 & 8 \\
\hline
\end{tabular}


${ }^{1}$ See Agénor and Montiel (1996), p. 423. See also, Mussa and Savastano (1999), p. 101.

${ }^{2}$ For conceptual discussions of the world CAPM see Frankel (1994); Stulz (1999a); Tesar (1999); Tesar and Werner (1995); and Tesar and Werner (1998).

${ }^{3}$ For surveys of the literature on imperfect capital market integration, see Stulz (1999a, b), Tesar (1999), Tesar and Werner (1998). For empirical evidence on the real effects of increased capital market integration, see Collins (1999) and Henry (2000a, b).

${ }^{4}$ Dividing the output cost by the total reduction in inflation gives the sacrifice ratio. See for example, Blanchard (1999), p. 368; Dornbusch and Fischer (1987), p. 528; and Mankiw (1997), p.352.

${ }^{5}$ See also Burton and Fischer (1998).

${ }^{6}$ See the data appendix for the definition of a successful stabilization.

${ }^{7}$ Lucas (2000) studies the welfare gains of reducing inflation. 